\title{
Snapping Shrimps (Decapoda: Caridea: Alpheidae) from the Dampier Archipelago, Western Australia
}

\author{
Mary K. Wicksten' and Matthew R. McClure 2 \\ 'Department of Biology, Texas A and $M$ University, College Station, \\ Texas 77843-3258, U.S.A \\ email: wickstenumail.bio.tamu.edu \\ 2Division of Mathematics and Sciences, Lamar State College-Orange, 410 Front Street, \\ Orange, Texas, 77630, U.S.A. \\ email: Matt.McClureoilsco.edu
}

\begin{abstract}
Forty-seven species of alpheid shrimp were collected by the Dampier Archipelago Expedition in 1998-2002. Six species are reported for the first time from northwestern Australia. The majority of the positively identified species $(18$, or $40 \%$ ) range widely from the western Indian Ocean and Red Sea to the central Pacific Ocean. Seventeen species $(38 \%)$ range from the western Indian Ocean into the western Pacific, six species $(13 \%)$ range from the eastern Indian Ocean into the western Pacific, and 4 species $(9 \%)$ range into the eastern Pacific. Three species of commensal shrimp were collected from corals and crinoids. Two species are strictly intertidal, 11 are strictly subtidal and 32 range from the lowest intertidal zone to subtidal depths. The majority of the shrimp inhabit areas of rocks, coral, shell or rubble, but Alpheus rapacida De Man, 1908 and A. serenei Tiwari, 1963 typically live in sandy or muddy areas. We follow the systematic treatment of Chace (1988) and Banner and Banner $(1973 ; 1975 ; 1982)$ for alpheids, but use a new subdivision, the "Alpheus armillatus" subdivision of the Alpheus edwardsii species group.
\end{abstract}

\section{INTRODUCTION}

Snapping shrimp (family Alpheidae) are common inhabitants of intertidal and shallow subtidal areas in temperate and tropical waters world-wide. Also known as pistol shrimps, these benthic crustaceans are characterized by having large chelate first pereopods, multi-articulate second pereopods and a distinct cardiac notch on the posterolateral margin of the carapace. Despite the common name, many species do not produce a snapping sound.

The taxonomy of snapping shrimps generally follows the pioneering work of Coutiere (1899; 1905; 1908; 1909). The most recent comprehensive works on alpheid shrimps of the Indo-Pacific area are those of Banner and Banner $(1973 ; 1975 ; 1982)$ and Chace (1988). Davie (2002) compiled a check list of alpheid species known at the time from Australia. These works provide detailed synonymies, keys and illustrations. Holthuis (1993) provided an illustrated key to all of the genera of alpheids known to the date of publication. Systematics of the Alpheidae has received less attention. Christoffersen (1987) supported the monophyly of the family. Banner and Banner (1973) considered as "lower" all alpheid genera lacking large chela of "excessive" size and asymmetrical development. The diverse genera in the family suggest numerous adaptations to different habitats. In the speciose genera Alpheus and Synalpheus, subspecific morphological groups have been proposed, but as yet no thorough syntheses of these taxa have been attempted, nor have morphometric analyses or molecular phylogenetic studies been attempted for most species. Recent work by Knowlton and Mills (1992) has found cryptic species, very similar in morphology but recognizable by colour patterns and geographic distribution. Williams et al. (2001) used nuclear and mitochondrial sequence data to suggest three major clades within the genus Alpheus, which combine several of the traditional informal morphological groups. We use an arrangement of genera similar to that presented in the key by Chace (1988).

\section{MATERIALS AND METHODS}

In this work, we provide an account of each species identified from the specimens taken by the 1998-2002 expeditions to the Dampier Archipelago by the Western Australian Museum. Detailed descriptions of the history of the expedition, sampling methods, maps, details of collecting sites 
and personnel, with maps, are given in Hutchins and Berry (2004), Hutchins and Fromont (2004), Hutchins et al. (2004), Jones (2004a, b), and SlackSmith (2004). We do not include a synonymy for each species, nor complete references to all original species descriptions. The reader is referred to the more comprehensive works by Banner and Banner (1973; 1975; 1982) and Chace (1988) for further information.

We include sex of the specimens when it could be determined; if it could not be determined, we use the abbreviation indet., meaning indeterminate, and ovig. to indicate ovigerous. We do not include specimens that were too small or damaged to be identified at least questionably to species.

After we completed identification of the specimens, they were returned to the Western Australian Museum. Regulations in the United States of America now include wet-preserved specimens in alcohol as "hazardous materials" and impose strict criteria for their shipment. As a result, we have been unable to re-examine the specimens to check identifications or measure them.

For each species, previous known range, habitat and depth are reported. Colour in life is given when reported. We include additional notes on taxonomy, hosts of commensal species, or unusual morphological variations where we are of the opinion that such information would add to that already known about the species.

All specimens have been deposited in the collections of the Western Australian Museum.

\section{SYSTEMATICS}

\section{Alpheopsis Coutière, 1896}

\section{Alpheopsis yaldwyni Banner and Banner, 1973}

\author{
Material examined \\ Western Australia, Dampier Archipelago. WAM \\ C 27752 (1 indet) DA3/99/49, Goodwyn I.
} $\left(20^{\circ} 32.397^{\prime} \mathrm{S}, 116^{\circ} 32.606^{\prime} \mathrm{E}\right), 3.0-9.0 \mathrm{~m}, 31.08 .99$.

\section{Previous reported range}

Indonesia, Micronesia, Japan; in Australia, from One Tree Island and Heron Island, Capricorn Group; near Cooktown, Queensland (Banner and Banner, 1973; Nomura and Asakura, 1998; Debelius, 1999). The collection from Goodwyn Island represents the first record of this species from northwestern Australia.

\section{Depth range and habitat}

"Broken-up coral heads from shallow water" (Banner and Banner, 1973). The specimen from Goodwyn Island was collected at a depth of $3-9 \mathrm{~m}$ on a sheltered reef with Porites bommies, interspersed with coral cover and some sandy interspaces.

\section{Colour in life}

Body with eight broad transverse bands of bright red. One band across each antennular appendage, one across distal end of palm, one down carapace medially, across each leg and one across tail (J.C. Yaldwyn, quoted by Banner and Banner, 1973). See photos in Kamezaki et al. (1988: 47), Gosliner et al. (1996: 208) and Debelius (1999: 154).

\section{Additional notes}

Chace (1988) reported finding specimens of Alpheopsis sp. similar in appearance to $A$. yaldwyni but coming from a much greater depth (nearly $550 \mathrm{~m}$ ) and having the proximal article in the carpus of the second pereopod proportionately longer than in A. yaldwyni. At the time of writing, no other specimens resembling those reported by Chace have been found. It seems likely from the depth alone that this specimen represents a different species.

\section{Salmoneus Holthuis, 1955}

\section{Salmoneus serratidigitus (Coutière, 1896)}

\section{Material examined}

Western Australia, Dampier Archipelago. WAM C 33665 (1 male, 1 female), DA2/99/91, 1.4 n. mls ESE of Tish Pt, Rosemary I. $\left(20^{\circ} 30.48^{\prime} \mathrm{S}, 116^{\circ} 36.53^{\prime} \mathrm{E}\right.$ to $\left.20^{\circ} 30.27^{\prime} \mathrm{S}, 116^{\circ} 36.86^{\prime} \mathrm{E}\right), 9.0-10.0 \mathrm{~m}, 26.07 .99$.

\section{Previous reported range}

Red Sea, eastern Africa, Madagascar, Aldabra, Seychelles, Philippines, Indonesia, Baja California, Mexico (Chace, 1988), Galapagos Islands (Wicksten, 1990), Queensland, Australia (Anker, 2003). The specimen from station DA2/91 represents a range extension into northwestern Australia.

\section{Depth range and habitat}

The species has been collected subtidally from hard bottoms (Wicksten, 1983). The specimen from the Dampier Archipelago was taken at a depth of 9-10 $\mathrm{m}$ amongst rocks, coral and shell.

\section{Colour in life}

Pale yellow (Wicksten, 1983).

\section{Additional notes}

Banner and Banner (1973) listed Salmoneus tricristatus, but not $S$. serratidigitus, from Australia. Salmoneus tricristatus can be distinguished from $S$. serratidigitus by the three obvious ridges running along the dorsal surface of the carapace in the former species, but absent in the latter. 
Athanas Leach, 1814

\section{Athanas dimorphus Ortmann, 1894}

Material examined

Western Australia, Dampier Archipelago. WAN ( 33670 ( I male, I female), DAl/98/11, Dolphin 1.12030.249' $11649.335 \mathrm{E})$, intertidal, 21.10 .98 : WANC 33651 (1 male), DA2/99/13, - 2.25 $\mathrm{n} \mathrm{mls}$ off Haü I. $(20 \% 26.52 \mathrm{~S}, 11700.50 \mathrm{~F}$ to 20) 26.27' $\left.11700.566^{\prime} \mathrm{E}\right)$, rake box drodge, $19.5 \mathrm{~m}$, 16.177.99; WAMC 33652 (1 make), DA2/99/78, -1.3 n. mls NF of NW Pt, Goodwen 1. 12031.09 s, $11633.04 \mathrm{l}$ to $2031.17 \mathrm{~S}, 11633.40 \mathrm{E}), 14.0-15.0 \mathrm{~m}$ 25.07.94: WAM C 33653 (1 male, I female ovig.) 1) 13444 42, Georgef Reef 12029.339's, 116 30.798E), intertidal, 28.08.99; WAM C 33654 (2 females ovig.), DA3/99/45, Rosemary I. (21) $29.67 \mathrm{I}^{\prime} \mathrm{S}, 116^{\circ} 35.894^{\prime} \mathrm{E}$ ), intertidal, 30.08.99. WAM C 33357 (1 male, 1 indet.), DA3/99/48, Goodwyn 1. (20 32.000'S, $\left.116^{\circ} 32.420^{\prime} \mathrm{E}\right)$, intertidal, 31.08.99; WAM C 27773 (1 female ovig.), DA3/99/ 54, Enderby 1. (20'36.222'S, $11633.063 \mathrm{E})$, intertidal, (12.(19994: WAM C 28081 (2 males, 3 ovig temales, 2 indet.). DA3/99/59, West Lewis 1 (20) $33.9475,11638.334 \mathrm{E}$ ), intertidal, 04.09.99; WAM ( 28085 (1 male, 3 ovig. females, 1 inder.), DA3/99/62, East Lewis I. (20\%37.499's, $11639.182 \mathrm{E}$ ), intertidal, 05.09.99; WAM C 28086 (1 male, 1 ovig. female, 1 indet.), DA3/99/62, East Lewis I. (20 37.499'S, $\left.116^{\circ} 39.182^{\prime} \mathrm{E}\right)$, intertidal, 05.09 .99

\section{Previous reported range}

East Africa, the Red Sea, Thailand, Japan, New Caledonia, Hong Kong, southern Philippines, eastern and western Australia (Banner and Banner, 1973); Maldive and Laccadive Archipelagoes, Marquesas and Society Islands (Chace, 1988).

\section{Depth range and habitat}

Occurring amidst detritus on shallow reef flats, rarely to a depth of $115 \mathrm{~m}$ (Chace, 1988). Specimens from the Dampier Archipelago were taken from the intertidal zone to a depth of $19.5 \mathrm{~m}$, amongst sand, rocks and silty areas near mangroves.

\section{Colour in life}

Bright red; tan and white striped; blue spot on dorsum of thorax (Moulton, in Banner and Banner, 1973). See photo in Kato and Okuno (2001: 49).

\section{Athanas djiboutensis Coutière, 1897}

\section{Material examined}

Western Australia, Dampier Archipelago. WAM C 33655 (1 male), DA3/99/47, Kendrew I (20 $\left.29.671^{\prime} \mathrm{S}, 116^{\circ} 32.519^{\prime} \mathrm{E}\right), 4.0-5.0 \mathrm{~m}, 30.08 .99$.
Previous reported range

Inrael, Red Sea, South Atria. Maldive and Iacadion Archipelagoes, Indonema, Philippines, Japan, Kiji, Tonge, Samen, Marahall. Rllice I'henenis Society and Marquesas lstands: in Mustralias, Heren Island and islets along the Com seal (Banner and Banner, 1973; (hace, 1988).

\section{Depth range and habitat}

Intertidal, amongst rocks and coral heads (Banney and Banner, 1973). The specimen from Kendrew Island was taken at a depth of $4-5 \mathrm{~m}$, amongst sand coral and algae.

\section{Colour in life}

White with scattered patches of brown spots and brown chromatophores. See photo in Kamezaki et al. (1988: 67).

\section{Athanas sibogae De Man, 1910}

\section{Material examined}

Western Australia, Dampier Archipelago WAM C 33656 (1 female ovig.), DA2/99/05, 4 n. mis NNW of Cohen 1. $\left(20^{\circ} 19.64^{\prime} \mathrm{S}, 116^{\prime} 45.75^{\prime} \mathrm{E}\right.$ to $\left.20^{\circ} 19.82^{\prime} \mathrm{S}, 116^{\circ} 45.98^{\prime} \mathrm{E}\right)$, rake box dredge, $38.0 \mathrm{~m}$, 14.07.99; WAM C 29517 (1 female, 1 indet.), DA2/99/66, $-2.75 \mathrm{n}$. mls ESE of Bluft Pt., Enderby 1. $\left(20^{\circ} 38.40^{\prime} \mathrm{S}, 11635.66^{\prime} \mathrm{E}\right.$ to $20^{\circ} 38.30^{\prime} \mathrm{S}$, $11636.01 \mathrm{E})$, rake box dredge, $7.2-7.7 \mathrm{~m}$, 23.07.88; WAM C 33361 (1 indet.), DA2/99/68, $\sim 3.6 \mathrm{n}$. mls $S$ of Bluff Pt., Enderby 1. (20 40.93's, $11633.21^{\prime} \mathrm{E}$ to $\left.20^{\circ} 40.63 \mathrm{~S}, 11633.36^{\prime} \mathrm{E}\right)$, rake box dredge, 9.0-9.2 m, 23.07.88; WAM C 33657 (l female), DA2/99/75, $-0.75 \mathrm{n} . \mathrm{m} / \mathrm{s} E$ of NE point of Goodwyn 1. $\left(20^{\circ} 32.16^{\circ} \mathrm{S}, 116^{\circ} 33.70^{\prime} \mathrm{E}\right.$ to $\left.20^{\circ} 31.70^{\prime} \mathrm{S}, 116^{\circ} 33.20^{\prime} \mathrm{E}\right)$, rake box dredge, 14.0$19.0 \mathrm{~m}, 25.07 .99$; WAM C 33658 (1 indet.), DA3/ 99/45, Rosemary 1. (20²9.671'S, $\left.116^{\circ} 35.894^{\prime} \mathrm{E}\right)$, intertidal, 30/08/99; WAM C 33659 (1 female), DA3/99/45, Rosemary I. (2029.671'S $116^{\circ} 35.894^{\prime} \mathrm{E}$ ) intertidal, 30/08/99; WAM C 27751 (1 female ovig.), DA3/99/48, Goodwyn I (20 32.000'S, $\left.116^{\circ} 32.420^{\prime} \mathrm{E}\right)$, intertidal, 31/08/99 WAM C 28072 (I female ovig., 2 indet.), DA3/99. 49. Goodwyn I. (2032.397'S, $\left.116^{\circ} 32.6066^{\prime} \mathrm{E}\right), 3.0-$ $9.0 \mathrm{~m}, 31 / 08 / 99$; WAM C $28074(2$ males, 1 indet.), DA3/99/50, Bare Rock (20 32.841's, $\left.116^{\circ} 26.733^{\prime} \mathrm{E}\right), 10.0-20.0 \mathrm{~m}, 31 / 08 / 99 ;$ WAM C 33660 (1 indet.), DA3/99/52, Roly Rock (2029.696' S, $\left.116^{\circ} 30.166 \mathrm{E}\right), 9.0-26.0 \mathrm{~m}, 01 / 09 / 99$; WAM C 33661 (1 male, 1 indet.), DA3/99/54, Enderby 1. (20 36.222'S, $\left.11633.063^{\prime} \mathrm{E}\right)$, intertidal, 01/09/99; WAM C 33663 (1 male, 1 indet.), DA3/ 99/56, Eaglehawk I. (2038.985'S, $\left.11626.210^{\prime} \mathrm{E}\right)$, 2.0-11.0 m, 03/09/99; WAM C 33664 (1 indet.), DA 3/99/56, Eaglehawk 1. (20\%38.985's, $\left.116^{\circ} 26.210^{\prime} \mathrm{E}\right), 2.0-11.0 \mathrm{~m}, 03 / 09 / 99 ;$ WAM C 
25547 (2 indet.), DA3/99/64, West Lewis I. (20 $\left.20^{\circ} 6.658^{\prime} \mathrm{S}, 116^{\circ} 36.956^{\prime} \mathrm{E}\right), 2.0-5.0 \mathrm{~m}, 06 / 09 / 99$.

\section{Previous reported range}

Red Sea, Singapore, Indonesia, Japan, Philippines, Tonga, Samoa. Western Australia across northern Australia to Capricorn Group (Banner and Banner, 1973).

\section{Depth range and habitat}

Intertidal to $70 \mathrm{~m}$, amongstst dead coral and sponges (Banner and Banner, 1973). Specimens from the Dampier Archipelago also were taken from shore to a depth of $19 \mathrm{~m}$, amongst rocks and near mud flats.

\section{Colour in life}

Pale blue with carmine red chromatophores; a broad longitudinal stripe without pigment or of pale yellow, antennular peduncle free from pigment or pale yellow, tail fan uniformly pale blue to deep purplish blue, eggs yellowish red (Banner and Banner, 1973).

\section{Alpheus Fabricius, 1798}

\section{Alpheus bidens (Olivier, 1811)}

\section{Material examined \\ Western Australia, Dampier Archipelago. WAM C 25650 (1 female ovig.), DA1/29, Legendre I. (20²4.566'S, $\left.116^{\circ} 53.714^{\prime} \mathrm{E}\right), 2.0-7.0 \mathrm{~m}, 27 / 10 / 98$.}

\section{Previous reported range}

Madagascar, Indonesia, Hong Kong, Ryukyu Is, Caroline and Marshall Islands, Australia from Perth, Western Australia) across to Heron Island in the Capricorn Group, Queensland; also Melbourne, Victoria, and Tasmania (Banner and Banner, 1982; Chace, 1988).

\section{Depth range and habitat}

Intertidal to $83 \mathrm{~m}$, amongst coral and sand (Chace, 1988). The specimen from Legendre Island was taken at a depth of 2-7 m amongst extensive coral cover.

\section{Colour in life}

Antennae with pink and brown stripes, chelae pale pink, small chela with fingers brown. Abdomen with uneven stripes of brown and pale pink (Banner and Banner, 1982). See photos in Kamezaki et al. (1988: 52) and Debelius (1999: 149).

\section{Additional notes}

Both Banner and Banner (1982) and Chace (1988) discuss variation in the locations and number of the teeth of the carapace. This variation may be related to size of the animal.

\section{Alpheus bisincisus De Haan, 1850}

\section{Material examined}

Western Australia, Dampier Archipelago. WAM C 25834 (1 female), DA1/98/01, Dolphin I. (20²5.852'S, $\left.116^{\circ} 52.953^{\prime} \mathrm{E}\right), 3.0-6.5 \mathrm{~m}, 17 / 09 / 98$; WAM C 25705 ( 1 male, 1 female), DA1/98/11, Dolphin I. $\left(20^{\circ} 30.249^{\prime} \mathrm{S}, 116^{\circ} 49.335^{\prime} \mathrm{E}\right)$, intertidal, 21.10.98; WAM C 25706 (1 female), DA1/98/11, Dolphin I. $\left(20^{\circ} 30.249^{\prime} \mathrm{S}, 116^{\circ} 49.335^{\prime} \mathrm{E}\right)$ intertidal, 21.10.98; WAM C 25916 (1 ovig. female), DA1/98/ 31 , Searipple Passage $\left(20^{\circ} 31.230^{\prime} \mathrm{S}, 116^{\circ} 51.182^{\prime} \mathrm{E}\right)$, intertidal, 28.10.98; WAM C 25908 (1 indet.), DA1/ 98/35, Legendre I. $\left(20^{\circ} 23.620^{\prime} \mathrm{S}, 116^{\circ} 51.960^{\prime} \mathrm{E}\right), 0.0-$ $1.0 \mathrm{~m}, 29.10 .98$; WAM C 33354 (1 male, 1 female ovig., 1 indet.), DA2/99/04, $4 \mathrm{n}$. mls NNW of Cohen I. $\left(20^{\circ} 19.64^{\prime} \mathrm{S}, 116^{\circ} 45.75^{\prime} \mathrm{E}\right.$ to $\left.20^{\circ} 19.82^{\prime} \mathrm{S}, 116^{\circ} 45.98^{\prime} \mathrm{E}\right)$, rake box dredge, $42.0-43.0 \mathrm{~m}, 14.07 .99$; WAM C 29499 (2 females, 2 indet.), DA2/99/12, $5.9 \mathrm{n} \mathrm{mls}$ NNW of NW point of Delambre I. $\left(20^{\circ} 20.75^{\prime} \mathrm{S}\right.$, $117^{\circ} 01.16^{\prime} \mathrm{E}$ to $\left.20^{\circ} 20.19^{\prime} \mathrm{S}, 117^{\circ} 01.18^{\prime} \mathrm{E}\right)$, rake box dredge, 32.0-34.0 m, 15.07.99; WAM C 29512 (1 male), DA2/99/26, $\sim 5.8 \mathrm{n}$. mls NE of Rosemary I. $\left(20^{\circ} 24.01^{\prime} \mathrm{S}, 116^{\circ} 41.28^{\prime} \mathrm{E}\right.$ to $\left.20^{\circ} 24.16^{\prime} \mathrm{S}, 116^{\circ} 40.83^{\prime} \mathrm{E}\right)$, rake box dredge, $34.0 \mathrm{~m}, 17.07 .99$; WAM C 29513 (1 male, 1 indet.), DA2/99/38, $2.1 \mathrm{n}$. mls WSW of Marks Pt, West Lewis I. ( $2.1 \mathrm{n}$. mls WSW of Marks $\mathrm{Pt}$, West Lewis $\mathrm{I}$.), rake box dredge, $11.0-13.0 \mathrm{~m}$, 17.07.99;WAM C 29529 (1 female), DA2/99/50, 6.5 n. mls W of Rocky Head, Enderby I. (20 37.10'S, $116^{\circ} 20.99^{\prime} \mathrm{E}$ to $20^{\circ} 37.28^{\prime} \mathrm{S}, 116^{\circ} 21.08^{\prime} \mathrm{E}$ ), rake box dredge, 24.0-25.0 m, 20.07.99; WAM C 29462 (1 female), DA2/99/70, $4.6 \mathrm{n}$. mls SSW of Bluff Pt, Enderby I. $\left(20^{\circ} 41.45^{\prime} \mathrm{S}, 116^{\circ} 30.78^{\prime} \mathrm{E}\right.$ to $20^{\circ} 41.27^{\prime} \mathrm{S}$, $\left.116^{\circ} 30.92^{\prime} \mathrm{E}\right)$, rake box dredge, $10.0 \mathrm{~m}, 24.07 .99$; WAM C 33353 ( 1 male, 1 female, 1 indet.), DA2/99/ 73, 24.07.99; $3.25 \mathrm{n}$ mls $\mathrm{S}$ of Rocky Head, Enderby I. $\left(20^{\circ} 40.14^{\prime} \mathrm{S}, 116^{\circ} 27.69^{\prime} \mathrm{E}\right.$ to $\left.20^{\circ} 39.93^{\prime} \mathrm{S}, 116^{\circ} 27.96^{\prime} \mathrm{E}\right)$, rake box dredge, $12.5 \mathrm{~m}, 24.07 .99$; WAM C 29446 (1 male, 1 female ovig.), DA2/99/85, $2.6 \mathrm{n}$. mls $E$ of $E$ point of Brigadier I. $\left(20^{\circ} 26.38^{\prime} \mathrm{S}, 116^{\circ} 39.76^{\prime} \mathrm{E}\right.$ to $20^{\circ} 26.09^{\prime} \mathrm{S}, 116^{\circ} 40.10^{\prime} \mathrm{E}$ ), rake box dredge, 28.0-29.0 m, 26.07.99; WAM C 29477 (2 indet.), DA2/99/99, $1.5 \mathrm{n} . \mathrm{mls}$ W of Rocky Head, Enderby I. $\left(20^{\circ} 36.98^{\prime} \mathrm{S}\right.$, $116^{\circ} 26.25^{\prime} \mathrm{E}$ to $\left.20^{\circ} 36.99^{\prime} \mathrm{S}, 116^{\circ} 26.36^{\prime} \mathrm{E}\right), 18.0-19.0 \mathrm{~m}$, 28.07.99; WAM C 27762 ( 1 male, 1 female ovig.), DA3/99/37, Malus Is $\left(20^{\circ} 30.632^{\prime} \mathrm{S}, 116^{\circ} 38.788^{\prime} \mathrm{E}\right)$, 2.0-3.5 m, 27.08.99; WAM C 27742 (1 female), DA3/ 99/44; Rosemary I. $\left(20^{\circ} 29.629^{\prime} \mathrm{S}, 116^{\circ} 34.425^{\prime} \mathrm{E}\right), 2.5-$ $6.0 \mathrm{~m}, 29.08 .99$; WAM C 27756 (1 male, 1 female ovig.), DA3/99/54, Enderby I. $\left(20^{\circ} 36.222^{\prime} \mathrm{S}\right.$, $116^{\circ} 33.063^{\prime} \mathrm{E}$ ), intertidal, 01/09/99; WAM C 28083 (1 male, 1 female ovig.), DA3/99/61, West Lewis I. $\left(20^{\circ} 34.693^{\prime}, 116^{\circ} 39.698^{\prime}\right), 3.0-5.0 \mathrm{~m}, 04.09 .99$; WAM C 26264, (1 female ovig.), DA3/99/68, Nelson Rocks (20²7.998'S, $\left.116^{\circ} 39.707^{\prime} \mathrm{E}\right), 6.5 \mathrm{~m}, 07.09 .99$.

\section{Previous reported range}

South Africa, Maldive and Laccadive 
Archipelagoes, Sri Lanka, Indonesia, Singapore, Japan, in Australia, from northwest Australia, Gulf of Carpentaria and southern Queensland (Banner and Banner, 1982).

\section{Depth range and habitat}

Intertidal to $45 \mathrm{~m}$, amongst mud and sand bottoms, also amongst weeds and sponges (Banner and Banner, 1982). The specimens from the Dampier Archipelago were taken from the intertidal zone to a depth of $29 \mathrm{~m}$, amongst sand, rocks and corals.

\section{Colour in life}

Most of body red, with small white spots on each side of abdomen, tips of chelae white to yellow. See photos in Debelius (1999: 146) and Minemizu (2000: 78).

\section{Additional notes}

Morphological features of Alpheus bisincisus may warrant its inclusion within the proposed "Alpheus armillatus" species complex of the Edwardsii group (McClure, 2002). Characters consistent with the complex include well-defined rostro-orbital depressions, the presence of spines on the midventral margins of the first several abdominal sternites in males, and the presence of the strong spine on the merus of the first pereopods. However, $A$. bisincisus possesses the balaeniceps feature on the minor chela of males, unlike the other species listed for the complex thus far.

\section{Alpheus bucephalus Coutière, 1904}

\section{Material examined}

Western Australia, Dampier Archipelago. WAM C 25713 (1 male), DA1/98/12, Angel I. (20³0.200'S, $116^{\circ} 47.250^{\prime} \mathrm{E}$ ), 2.0-7.0 m, 21.10.98; WAM C 33074 (1 male, 1 female ovig.), DA1/98/34, Tozer I. $\left(20^{\circ} 27.684^{\prime} \mathrm{S}, 116^{\circ} 50.486^{\prime} \mathrm{E}\right)$, intertidal, 29.10.98; WAM C 33599 (1 indet.), DA2/99/77, 1.8 n. mls NW of NW point of Goodwyn I. (20 30.57'S, $116^{\circ} 30.89^{\prime} \mathrm{E}$ to $20^{\circ} 30.49^{\prime} \mathrm{S}, 116^{\circ} 30.91^{\prime} \mathrm{E}$ ), rake box dredge, 13.0-14.0 m, 25.07.99; WAM C 33600 (2 males, 2 ovig. females), DA3/99/42, Georgeff Reef (20²9.339'S, $\left.116^{\circ} 36.798^{\prime} \mathrm{E}\right)$, intertidal, 28.08.99; WAM C 33601 (1 indet.), DA3/99/52, Roly Rock ( $\left.20^{\circ} 29.696^{\prime} \mathrm{S}, 116^{\circ} 30.166^{\prime} \mathrm{E}\right), 9.0-26.0 \mathrm{~m}, 01.09 .99$.

\section{Previous reported range}

Red Sea to Mozambique, across the Indian Ocean to Indonesia, in the Pacific from Philippines and Japan to the Line and Society Islands, western Australia across to Heron Island in the Capricorn Group (Banner and Banner, 1982).

\section{Depth range and habitat}

Intertidal to $80 \mathrm{~m}$, living in tubes made up of algae and sponges, amongst coral heads (Banner and Banner, 1982; Chace, 1988). The specimens from the Dampier Archipelago were collected from shore to a depth of $14 \mathrm{~m}$, amongst corals, sponges and rocks.

\section{Colour in life}

Body and chelae transparent with scattered, green chromatophores (Yaldwyn, in Banner and Banner, 1982).

\section{Alpheus digitalis De Haan, 1844}

\section{Material examined}

Western Australia, Dampier Archipelago. WAM C 29528 (1 male), DA1/98/11, Dolphin I. $\left(20^{\circ} 30.249^{\prime} \mathrm{S}, 116^{\circ} 49.335^{\prime} \mathrm{E}\right)$, intertidal, 21.10.98.

\section{Previous reported range}

Mergui Arch., Singapore, China, Japan, in Australia from near Perth, Western Australia, across to Botany Bay, New South Wales (Banner and Banner, 1982; Hayashi and Nagata, 2002).

\section{Depth range and habitat}

To a depth of $38 \mathrm{~m}$, in brackish water at mouths of rivers (Banner and Banner, 1982). The specimen from Dolphin Island was taken in the intertidal zone on a reef flat with igneous boulders and also a flowing creek exiting muddy mangroves, with several pools in a muddy bottom.

\section{Colour in life}

Green to brown dorsally, colourless to pale blue laterally, with longitudinal streaks on the abdomen, tips of the chelae orange to pink, other legs lighter in colour (Banner and Banner, 1982). See Hayashi and Nagata (2002, fig. 2) for colour photographs.

\section{Additional notes}

Hayashi and Nagata (2002) synonymized $A$. distinguendus de Man, 1909, with A. distinguendus. The specimens originally were identified as $A$. distinguendus.

\section{Alpheus dolerus Banner, 1956}

\section{Material examined}

Western Australia, Dampier Archipelago. WAM C 29453 (1 female), DA2/99/05, $3.5 \mathrm{n}$. mls NE of C. Legendre $\left(20^{\circ} 19.79^{\prime} \mathrm{S}, 116^{\circ} 53.85^{\prime} \mathrm{E}\right.$ to $20^{\circ} 19.81^{\prime} \mathrm{S}$, $116^{\circ} 53.39^{\prime} \mathrm{E}$ ), rake box dredge, $38.0 \mathrm{~m}, 14 / 07 / 99$.

\section{Previous reported range}

Somalia, Madagascar, Philippines, Marianas, Marshall, Gilbert, Cook and Society Islands, Hawaii; in Australia, from Diamond Islet in the 
Coral Sea to Heron 1. in the Capricom Group, Queensland (Banner and Banner, 1982, Chace, 1988). This is the first record of the species from northwestern Australia.

\section{Depth range and habitat}

Occurring to a depth of $4 \mathrm{~m}$, amongst coral (Banner and Banner, 1982). The specimen from the Dampier Archipelago was taken at a depth of $38 \mathrm{~m}$ amongst rock, muddy sand, sponges, soft corals and gorgonians.

\section{Colour in life}

Not reported.

Alpheus eulimene? De Man, 1909

\section{Material examined}

Western Australia, Dampier Archipelago. WAM C 25915 (1 female), DA1/98/01, Dolphin $\mathrm{I}$. (20'25.852'S, $\left.116^{\circ} 52.953 \mathrm{E}\right), 3.0 \sim 6.5 \mathrm{~m}, 17.10 .98$.

\section{Previous reported range}

Maldive Archipelago, Indonesia, Philippines, Japan, Mariana Islands; in Australia, from Western Australia across to Heron Island, Capricorn Groupr Queensland (Banner and Banner, 1982).

\section{Depth range and habitat}

Subtidal to $410 \mathrm{~m}$, amongst sponges or dead corals (Banner and Banner, 1982; Chace, 1988). The specimen from Dolphin Island was taken at a depth of 3-6.5 m amongst corals

\section{Colour in life}

Not reported.

\section{Additional notes}

The specimen reported herein lacks the characteristic second pereopods, and cannot be identified to species with certainty. However, the forms of the rostrum, scaphocerite and telson closely match those illustrated by Banner and Banner (1982, fig. 27).

\section{Alpheus facetus De Man, 1908}

\section{Material examined}

Western Australia, Dampier Archipelago. WAM C 25660 (1 male, 1 female), DA1/98/34, Tozer I. (2027.684'S, $\left.116^{\circ} 50.486^{\prime} \mathrm{E}\right)$, intertidal, 29.10.98.

\section{Previous reported range}

Viet Nam, Thailand, Indonesia, Philippines, Japan, Caroline Islands; in Australia, from western Australia across to eastern Australia near Sydney,
New South Wales (Banner and Banner, 1982; Chace, 1988).

\section{Depth range and habitat}

Intertidal to $30 \mathrm{~m}$, usually at $6 \mathrm{~m}$ or less, amongst dead coral heads (Banner and Banner, 1982). The specimen from Tozer Island was taken in the intertidal zone, amongst silty flats, coral rubble and oyster-covered rocks.

\section{Colour in life}

Two longitudinal brown bands separated by middorsal pinkish tan band. Chelae with more or less continuation of brown band. Tail fan dark at base, then with light band adjacent to this, and terminated by dark green band (Banner and Banner, 1982).

\section{Alpheus gracilipes Stimpson, 1861}

\section{Material examined}

Western Australia, Dampier Archipelago. WAM C 33666 (1 male), DA3/99/54, Enderby I. $\left(20^{\circ} 36.222^{\prime} \mathrm{S}, 116^{\circ} 33.063 \mathrm{E}\right)$, intertidal, 01/09/99.

\section{Previous reported range}

Red Sea, East Africa, Indonesia, Vietnam, Korea, Hong Kong, Japan, New Caledonia, across the central Pacific to Hawaii and Tahiti, in Australia, from western Australia across to Heron Island in the Capricorn Group, Queensland (Banner and Banner, 1982; Chace, 1988).

\section{Depth range and habitat}

Intertidal to $6 \mathrm{~m}$, under rocks and dead coral (Banner and Banner, 1982; Chace, 1988). The specimen from Enderby Island was taken along the shore in a bay with a tidal mud flat.

\section{Colour in life}

Body blue with oblong irregular patches of white sprinkled with orange-red pigment spots, giving overall rusty appearance. Chelipeds and other thoracic legs blue tinged with orange-red. Pleura of second to fourth abdominal somites with large round black spot tinged with orange (Banner and Banner, 1982). See photo in Kamezaki et al. (1988: 57).

\section{Alpheus gracilis Heller, 1862}

\section{Material examined}

Western Australia, Dampier Archipelago. Uncatalogued (1 male), DA 2/99/38, $\sim 2.1 \mathrm{n} . \mathrm{mls}$ WSW of Marks Pt, West Lewis I. (20037.47'S, $116^{\circ} 35.37^{\prime} \mathrm{E}$ to $\left.20^{\circ} 36.91^{\prime} \mathrm{S}, 116^{\circ} 35.33^{\prime} \mathrm{E}\right)$, rake box dredge, $11.0-13.0 \mathrm{~m}, 19.07 .99$ 


\section{Previous reported range}

Red Sea, eastern and possibly South Africa to Thailand, Philippines, lapan, Indonesia, Hawaii and the Society Islands; in Australia, from Stradbrohe lsland, and off Port Douglas, Queensland (Banner and Banner, 1982; Chace, 1988). This is the first recont of the species from northwestern Australia.

\section{Depth range and habitat}

Intertidal and subtidal (Banner and Banner, 1982). The specimen from the Dampier Archipelago was collected at a depth of $11-13 \mathrm{~m}$ on a mixed bottom with rocks, mud, algae, sponges, hvdroids and gorgonians.

\section{Colour in life}

Reddish gray, reddish bands near middle of carapace to posterior end of abdomen, irregular bands on the chelae; external spine of uropod brown to black (Banner and Banner, 1982).

Alpheus inopinatus Holthuis and Gottlieb, 1958

\section{Material examined}

Western Australia, Dampier Archipelago. WAM C 27734 (1 male, 1 female ovig.), DA3/99/38, Malus Is $\left(20^{\circ} 30.632^{\prime} \mathrm{S}, 11638.788^{\prime} \mathrm{E}\right)$, intertidal, 27.08.99; WAM C 27770 (1 male, 1 female ovig.), DA3/99/66, Enderby I. (20 $36.700^{\circ}$ S, $\left.116^{\circ} 31.293^{\prime} \mathrm{E}\right)$, intertidal, 06.09 .99

\section{Previous reported range}

Mediterranean coast of Israel. West Pakistan; in Australia, from Perth, Western Australia across the northern coast to Grafton, New South Wales (Banner and Banner, 1982).

\section{Depth range and habitat}

Intertidal, under rocks (Banner and Banner, 1982). The precincur from the Dampier Archipelago were uted in the intertidal ront amongst coral rubble, shells, limestone slabs and mud.

\section{Colour in life}

Vin reported.

\section{Alpheus lobidens De Haan, 1850}

\section{Material examined}

Western Australia, Dampier Archipelago. WAM (27737 (1 male), DA3/99/41, Ceorreff Reerfs (21) $29.339 \mathrm{~S}, 11636.798 \mathrm{E}), 1.04 .0 \mathrm{~m}, 28-29.08 .99$

Previous reported range

Entire Inderlacibs area from the Red sea to Hawait; astern and chetral Vediteranean; in
Australia, from the Houtman Abrolhos lstands. Western Australia, across northern Australia to Sydney, New South Wales, also lord Howe I (Banner and Banner, 1982: Chace, 1988).

\section{Depth range and habitat}

Intertidal to $25 \mathrm{~m}$, in mud or amongst bases of dead coral heads; may associate with gobiid fish (Banner and Banner, 1982; Chace, 1988). The specimen from Georgeff Reefs was taken at a depth of 1-4 $\mathrm{m}$ amongst coralline sand and dead coral.

\section{Colour in life}

Greenish brown, olive green or smokv gray, anterior parts of abdominal segments often white, with or without longitudinal stripes, black spot on middle of side on abdominal segments two and four, telson and uropods with black tips, chelae greenish orange or green-brown, fingers and thumb of major chela orange, palm with brilliant cobalt blue patch on inner surface, other legs dull pinkish (Banner and Banner, 1982). See photo in Debelius (1999: 146).

\section{Additional notes}

Nomura and Anker (2000) suggested that more than one species has been confounded under the name A. lobidens.

\section{Alpheus lottini (Guérin, 1829)}

Material examined

Western Australia, Dampier Archipelago. WAM C 25884 (1 female ovig.), DA1/04, Legendre I. (20²4.320'S, $\left.116^{\circ} 56.108^{\circ} \mathrm{E}\right), 12.0-18.0 \mathrm{~m}, 18.10 .98$; WAM C 27741 (1 juv.), DA3/99/44; Rosemary 1. (20²9.629'S, $\left.11634.425^{\prime} \mathrm{E}\right), 2.5-6.0 \mathrm{~m}, 29.08 .99$.

\section{Previous reported range}

Red Sea, east and South Africa, throughout the Indo-Pacific region, Gulf of California to Galapagos Is (Banner and Banner, 1982; Wicksten, 1983).

\section{Depth range and habitat}

Intertidal to $50 \mathrm{~m}$, always amongst living pocilloporid corals (Pocillopora spp and related species). The specimens from the Dampier Archipelago were taken at depths of $2.5-18.0 \mathrm{~m}$, amongst Pocillopora damicomis.

\section{Colour in life}

Varable. Mottled bright orange-red with dark red mottling, may have mid-longitudinal stripe of deep red that may appear almost black (Bamer and Banner, 1982). See photes by Kerstitch (1984: 80), Hover (1998: 230), Debelius (1999: 1+7), Minemi/u $(2000: 77)$ and fones and Morgan $(2002: 65)$ 


\section{Additional notes}

See Chace (1988) for information on the taxonomic designation of this species.

\section{Alpheus malleodigitus (Bate, 1888)}

\section{Material examined}

Western Australia, Dampier Archipelago. WAM C 29507 (1 male, 1 female, 3 ovig. females), DA2/99/ $77, \sim 1.8 \mathrm{n}$. mls NW of NW point of Goodwyn I. $\left(20^{\circ} 30.57^{\prime} \mathrm{S}, 116^{\circ} 30.89^{\prime} \mathrm{E}\right.$ to $\left.20^{\circ} 30.49^{\prime} \mathrm{S}, 116^{\circ} 30.91^{\prime} \mathrm{E}\right)$, rake box dredge, $13.0-14.0 \mathrm{~m}, 25.07 .99$; WAM C 33602 ( 2 females, 1 female ovig.), DA2/99/95, 1.1 n. mls W of Bluff Pt $\left(20^{\circ} 37.37^{\prime} S, 116^{\circ} 31.69^{\prime} \mathrm{E}\right.$ to $\left.20^{\circ} 37.45^{\prime} \mathrm{S}, 116^{\circ} 31.58^{\prime} \mathrm{E}\right), 5.0-7.0 \mathrm{~m}, 27.07 .99$; WAM C 33603 (1 male), DA3/99/70, Nelson Rocks $\left(20^{\circ} 27.441^{\prime} \mathrm{S}, 116^{\circ} 39.588^{\prime} \mathrm{E}\right), 5.0-7.0 \mathrm{~m}, 08.09 .99$.

\section{Previous reported range}

The Red Sea, eastern Africa, Indonesia, Hong Kong, Japan, across the Pacific to the Society Islands; in Australia, from the Dampier Archipelago, Western Australia across northern waters to Heron Island, Capricorn Group, Queensland (Banner and Banner, 1982; Chace, 1988).

\section{Depth range and habitat}

In galleries under coralline encrusting algae on heads of dead coral, usually in the surf zone (Banner and Banner, 1982; Chace, 1988). Kropp (1987) illustrated the tunnel systems of this species, found amongst Porites spp. The specimens from the Dampier Archipelago came from depths of 0-14 m, amongst rocks and corals.

\section{Colour in life}

Female off pinkish-red, male tan (Banner and Banner, 1982). See photos in Kamezaki et al. (1988: 59) and Debelius (1999: 146).

\section{Additional notes}

Banner and Banner (1982) suggested that $A$. obesomanus, A. malleodigitus and A. microstylus (Bate) might be variants of the same species. However, in their analysis of the morphology, the three species could be separated on the basis of the antennal and antennular peduncles, proportions of the articles of the carpus of the second pereopods, proportions of the carpus to the merus of the third pereopod and length to width ratio of the telson. Our specimens were readily identifiable as $A$. malleodigitus and did not come from the same stations as specimens of A. obesomanus. Kropp (1987) also distinguished between $A$. obesomanus and $A$. malleodigitus and demonstrated that the two species live in slightly different habitats.

\section{Alpheus miersi Coutière, 1898}

\section{Material examined}

Western Australia, Dampier Archipelago. WAM C 33771 (1 indet.), DA2/99/50, 6.5 n. mls W of Rocky Head, Enderby I. (20³7.10'S, 116 $20.99^{\prime} \mathrm{E}$ to $\left.20^{\circ} 37.28^{\prime} \mathrm{S}, 116^{\circ} 21.08^{\prime} \mathrm{E}\right)$, rake box dredge, $24.0-25.0$ m, 20.07.99.

\section{Previous reported range}

Somalia, Madagascar, Seychelles, Maldive and Laccadive Archipelagoes, Sri Lanka, Indonesia, Philippines, Japan; in Australia, islands and coast of Queensland ( Banner and Banner, 1982; Chace, 1988). This is the first record from northwestern Australia.

\section{Depth range and habitat}

Intertidal (Banner and Banner, 1982). The specimen from the Dampier Archipelago was collected at a depth of 24-25 m amongst rocks, shell fragments, algae, sponges, gorgonians and other invertebrates.

\section{Colour in life}

Not reported.

\section{Alpheus obesomanus Dana, 1852}

\section{Material examined}

Western Australia, Dampier Archipelago. WAM C 25869 (1 female ovig.), DA1/98/08, Angel I. (20⒉180'S, $\left.116^{\circ} 47.711^{\prime} \mathrm{E}\right), 2.0-8.0 \mathrm{~m}, 20.10 .98$; WAM C 25694 (1 indet.), DA1/98/13, Hamersley Shoal $\left(20^{\circ} 23.203^{\prime} \mathrm{S}, 116^{\circ} 46.691^{\prime} \mathrm{E}\right), 1.0-16.0 \mathrm{~m}$, 21.10.98; WAM C 33604 (1 female ovig.), DA2/99/ $76, \sim 0.4 \mathrm{n} \mathrm{mls} \mathrm{W}$ of NW point of Goodwyn I., (20³2.11'S, $116^{\circ} 31.55^{\prime} \mathrm{E}$ to $\left.20^{\circ} 32.40^{\prime} \mathrm{S}, 116^{\circ} 31.22^{\prime} \mathrm{E}\right)$, rake box dredge, $13.0-15.0 \mathrm{~m}, 25.07 .99$; WAM C 33605 (1 female ovig.), DA2/99/84; $2.9 \mathrm{n} \mathrm{mls} \mathrm{E}$ of Tish Pt, Rosemary I. $\left(20^{\circ} 29.94 ' \mathrm{~S}, 116^{\circ} 38.11^{\prime} \mathrm{E}\right.$ to $\left.20^{\circ} 29.84^{\prime} \mathrm{S}, 116^{\circ} 38.64^{\prime} \mathrm{E}\right)$, rake box dredge, 12.5-15.0 m, 26.07.99; WAM C 28082 (1 female), DA3/99/60, West Lewis I. $\left(20^{\circ} 32.878^{\prime} \mathrm{S}, 116^{\circ} 39.518^{\prime} \mathrm{E}\right), 1.5-7.0 \mathrm{~m}$, 04.09.99.

\section{Previous reported range}

Red Sea, Madagascar to the Society Islands, including Japan; in Australia, from Torres Straits to the Capricorn Group, Queensland (Banner and Banner, 1982). This is the first record of the species from northwestern Australia.

\section{Depth range and habitat}

Shore, in galleries under coralline encrusting algae on heads of dead coral, deep burrows on living Acropora species (Banner and Banner, 1982). Kropp (1987) found this species living in galleries 
in dead coral and living Millepora platyphylla and Heliopora coerulea. The specimens from the Dampier Archipelago were collected from the lowest intertidal zone to a depth of $17 \mathrm{~m}$, amongst rocks, shelly sand and corals.

\section{Colour in life}

Sulphur yellow (Banner and Banner, 1982). In the photo by Kamezaki et al. (1988: 60), the specimen is shown to have a yellow cephalothorax and chelae. The abdomen is brown with a mid-dorsal white stripe, the tail fan is brown and the rest of the pereopods are brown with pale rings at the articulations of the segments.

\section{Alpheus pacificus Dana, 1852}

\section{Material examined}

Western Australia, Dampier Archipelago. WAM C 25710 (1 male), DA1/98/03, Legendre I. (20²4.320'S, $\left.116^{\circ} 56.108^{\prime} \mathrm{E}\right), 2.0-15.0 \mathrm{~m}, 18.10 .98$; WAM C 25712 (1 female ovig.), DA1/98/03, Legendre I. (20²4.320'S, $\left.116^{\circ} 56.108^{\prime} \mathrm{E}\right), 2.0-15.0 \mathrm{~m}$, 18/10/98; WAM C 25716 (2 females ovig.), DA1/98/ 09. Angel I. (20²8.692'S, $\left.116^{\circ} 47.950^{\prime} \mathrm{E}\right), 2.0-3.0 \mathrm{~m}$, 20.10.98; WAM C 25717 (1 female ovig.), DA1/98/ 09, Angel I. (20²8.692'S, $116^{\circ} 47.950^{\prime} \mathrm{E}, 2.0-3.0 \mathrm{~m}, 20$ / 10/98; WAM C 28067 (1 male, 3 females ovig., 1 indet.), DA3/99/42, Georgeff Reef $\left(20^{\circ} 29.339^{\prime} \mathrm{S}\right.$, $116^{\circ} 36.798^{\prime} \mathrm{E}$ ), intertidal, 28.08.99; WAM C 27743 (2 males), DA3/99/45, Rosemary I. $\left(20^{\circ} 29.671^{\prime} \mathrm{S}\right.$, $116^{\circ} 35.894^{\prime} \mathrm{E}$ ), intertidal, 30/08/99; WAM C 27745 (1 male), DA3/99/45, Rosemary I. (20²9.671'S, $\left.116^{\circ} 35.894^{\prime} \mathrm{E}\right)$, intertidal, 30/08/99; WAM C 27746 (1 male), DA3/99/45, Rosemary I. $\left(20^{\circ} 29.671^{\prime} \mathrm{S}\right.$, $116^{\circ} 35.894^{\prime} \mathrm{E}$ ), intertidal, 30/08/99; WAM C 27749 (1 female ovig.), DA3/99/48, Goodwyn I. (20³2.000'S, $\left.116^{\circ} 32.420^{\prime} \mathrm{E}\right)$, intertidal, 31/08/99.

\section{Previous reported range}

The Red Sea and eastern Africa across the IndoPacific region to Socorro Island, Isla del Coco, Clipperton Island, and the Galapagos Islands; in Australia, from Perth, Western Australia, across northern Australia to Sydney, New South Wales; also Lord Howe and Norfolk Islands (Banner and Banner, 1982; Kim and Abele, 1988).

\section{Depth range and habitat}

Mostly intertidal, to $20 \mathrm{~m}$, under rocks in clean sand (Banner and Banner, 1982). The specimens from the Dampier Archipelago were taken from the intertidal zone to a depth of $15 \mathrm{~m}$, amongst rocks, sand and limestone slabs.

\section{Colour in life}

Antennae blue, antennules olive green. Large chela banded with irregular white, olive green and blue green, tips brown. Fingers of small chela light green, palm with distal 0.75 of length white, olive green at base; carpus blue. Other thoracic legs blue with white band and meral-carpal joint. Carapace and abdomen reddish brown with faint brown line from middle of carapace to sixth abdominal somite, diffuse white spot where each abdominal somite meets the next; telson same colour as abdomen, uropods green (Gillett, in Banner and Banner, 1982).

\section{Additional notes}

Kim and Abele (1988) reported this species from the Gulf of California, Mexico, but did not provide either locality data or a reference. The species has been reported from Socorro Island, but this island lies outside of the Gulf of California.

\section{Alpheus paralcyone Coutière, 1905}

\section{Material examined}

Western Australia, Dampier Archipelago. WAM C 33606 (1 female ovig.), DA2/99/76, $0.4 \mathrm{n} \mathrm{mls} \mathrm{W}$ of NW point of Goodwyn I. $\left(20^{\circ} 32.11^{\prime} \mathrm{S}, 116^{\circ} 31.55^{\prime} \mathrm{E}\right.$ to $20^{\circ} 32.40^{\prime} \mathrm{S}, 116^{\circ} 31.22^{\prime} \mathrm{E}$ ), rake box dredge, $13.0_{-}$ $15.0 \mathrm{~m}, 25.07 .99$.

\section{Previous reported range}

Madagascar to Indonesia, Philippines, Japan, Pacific islands to Hawaii; in Australia, from Carnarvon, Western Australia, across northern Australia to Heron Island, Capricorn Group, Queensland (Banner and Banner, 1982; Chace, 1988).

\section{Depth range and habitat}

Immediate subtidal zone to $90 \mathrm{~m}$, amongst dead coral heads (Banner and Banner, 1982). The specimen from the Dampier Archipelago was taken at a depth of 13-15 $\mathrm{m}$ amongst sand, algae, corals and other marine invertebrates.

\section{Colour in life}

Not reported.

\section{Alpheus pareuchirus pareuchirus Coutière, 1905}

\section{Material examined}

Western Australia, Dampier Archipelago. WAM C 25862 (1 female ovig.), DA1/98/01, Dolphin I. $\left(20^{\circ} 25.852^{\prime} \mathrm{S}, 116^{\circ} 52.953^{\prime} \mathrm{E}\right), 3.0-6.5,17 / 09 / 98 ;$ WAM C 25866 (1 male), DA $1 / 98 / 01$, Dolphin I. (2025.852'S, 116 52.953'E), 3.0-6.5, 17/09/98; WAM C 29532 (2 indet.), DA2/99/32, 4.8 n. mls NE of Courtenay Head Light, Malus I., (20²6.95'S, $116^{\circ} 44.86^{\circ} \mathrm{E}$ to $20^{\circ} 27.395,116^{\circ} 44.28^{\prime} \mathrm{E}$ ), rake box dredge, 15.0-16.0 m, 18.07.99; WAM C 29490 (1 female, 1 female ovig.), DA2/99/47, $3.9 \mathrm{n}$. mls just 
$\mathrm{N}$ of $\mathrm{W}$ of Rocky Head, Enderby I. (20 $36.58^{\circ} \mathrm{S}$, $116^{\circ} 23.66^{\prime} \mathrm{E}$ to $\left.2036.58^{\prime} \mathrm{S}, 116^{\circ} 24.26 \mathrm{E}\right)$, rake box dredge, $20.0-22.5 \mathrm{~m}, 20.07 .99$.

\section{Previous reported range}

The Red Sea, Madagascar, Seychelles, Maldives, Thailand, Indonesia, Philippines, Caroline Islands; in Australia, from Port Hedland, Western Australia and the Percy Islands, Queensland (Banner and Banner, 1982; Chace, 1988). This is the first report of the species from the Dampier Archipelago.

\section{Depth range and habitat}

Depth $3 \mathrm{~m}$ and deeper, usually deeper than $15 \mathrm{~m}$ (Banner and Banner, 1982). The specimens from the Dampier Archipelago were taken at depths of 3$22.5 \mathrm{~m}$ amongst corals, rock, sand, algae, sponges and other marine invertebrates.

\section{Colour in life}

Not reported.

\section{Alpheus parvirostris Dana, 1852}

\section{Material examined}

Western Australia, Dampier Archipelago. WAM C 25664 (1 female), DA1/98/01, Dolphin I. (2025.852'S, 116 52.953 'E), 3.0-6.5 m, 17/09/98; WAM C 25644 (1 male), DA1/98/06, Haüy I. $\left(20^{\circ} 25.725^{\prime} \mathrm{S}, 116^{\circ} 57.580^{\prime} \mathrm{E}\right), 0.5-2.0 \mathrm{~m}, 19.10 .98$; WAM C 25667 (1 female), DA1/98/08, Angel I. $\left(20^{\circ} 29.180^{\prime} \mathrm{S}, 116^{\circ} 47.711 \mathrm{E}\right), 2.0-8.0 \mathrm{~m}, 20.10 .98$; WAM C 25669 (1 indet.), DA1/98/08, Angel I. (2029.180'S, $\left.116^{\circ} 47.711^{\prime} \mathrm{E}\right), 2.0-8.0 \mathrm{~m}, 20 / 10 / 98$; WAM C 25849 (1 female), DA1/98/08, Angel I. (20²9.180'S, $\left.116^{\circ} 47.711^{\prime} \mathrm{E}\right), 2.0-8.0 \mathrm{~m}, 20 / 10 / 98$; WAM C 25857 (1 female), DA1/98/08, Angel I. (20²9.180'S, $\left.116^{\circ} 47.711^{\prime} \mathrm{E}\right), 2.0-8.0 \mathrm{~m}, 20 / 10 / 98$; WAM C 25646 (1 male, 2 females ovig.), DA1/98/ 31, Searipple Passage (20³1.230'S, 116 $\left.51.182^{\prime} \mathrm{E}\right)$, intertidal, 28.10.98; WAM C 25677 (1 male), DA1/ 98/35, Legendre I. (20²3.620'S, $\left.116^{\circ} 51.960^{\prime} \mathrm{E}\right), 0.0-$ $1.0 \mathrm{~m}, 29.10 .98$; WAM C 33362 (2 females), DA2/ 99/76, $\sim 0.4 \mathrm{n} \mathrm{mls}$ W of NW point of Goodwyn I. $\left(20^{\circ} 32.11^{\prime} \mathrm{S}, \quad 116^{\circ} 31.55^{\prime} \mathrm{E}\right.$ to $20^{\circ} 32.40^{\prime} \mathrm{S}$, $\left.116^{\circ} 31.22^{\prime} \mathrm{E}\right)$, rake box dredge, $13.0-15.0 \mathrm{~m}$, 25.07.99; WAM C 29535 (1 female), DA3/99/37, Malus Is $\left(20^{\circ} 30.632^{\prime} \mathrm{S}, 116^{\circ} 38.788^{\prime} \mathrm{E}\right), 2.0-3.5 \mathrm{~m}$, 27.08.99; WAM C 27739 (2 indet.), DA3/99/41, Georgeff Reefs $\left(20^{\circ} 29.339^{\prime} \mathrm{S}, 116^{\circ} 36.798^{\prime} \mathrm{E}\right), 1.0-4.0$ m, 28-29.08.99; WAM C 27747 (1 male, 1 female), DA3/99/47, Kendrew I. (20²9.671'S, $\left.116^{\circ} 32.519^{\prime} \mathrm{E}\right), 4.0-5.0 \mathrm{~m}, 30.08 .99$; WAM C 29540 (1 female ovig.), DA3/99/61, West Lewis I. (2034.693'S, 116 39.698'E), 3.0-5.0 m, 04.09.99; WAM C 27767 (2 indet.), West Lewis I. (20 36.658'S, 116 36.956' E), 2.0-5.0 m, 06/09/99.

\section{Previous reported range}

The Red Sea, eastern and South Africa to Japan, Philippines, Indonesia, to Tuamotu Archipelago, but not Hawaii; in Australia, from the Houtman Abrolhos, Western Australia, across northern Australia to the Capricorn Group, Queensland (Banner and Banner, 1982; Chace, 1988).

\section{Depth range and habitat}

Intertidal to $32 \mathrm{~m}$, abundant on reef flats in dead coral, occasionally in living coral and sponges (Chace, 1988). Specimens from the Dampier Archipelago were collected from the shore to a depth of $8 \mathrm{~m}$, amongst corals, sand, algae, and sponges.

\section{Colour in life}

Body transparent, chelae green, broad dark brown or green bands across abdomen, tips of fingers of major chela opaque, white (Banner and Banner, 1982). See photo in Kamezaki et al. (1988: 61).

\section{Additional notes}

Many of the specimens lack a sharp tooth on the merus of the third and fourth pereopods, a distinctive feature used in the identification key by Banner and Banner (1982). However, they noted this variation in their discussion of the species. The long basicerite, exceeding the length of the first article of the antennular peduncle, is characteristic.

\section{Alpheus polyxo De Man, 1909}

\section{Material examined}

Western Australia, Dampier Archipelago. WAM C 29536 (1 male, 1 female ovig.), DA2/99/04, 4 n. mls NNW of Cohen I. $\left(20^{\circ} 19.64^{\prime} \mathrm{S}, 116^{\circ} 45.75^{\prime} \mathrm{E}\right.$ to $\left.20^{\circ} 19.82^{\prime} \mathrm{S}, 116^{\circ} 45.98^{\prime} \mathrm{E}\right)$, rake box dredge, 42.0-43.0 m, 14.07.99; WAM C 29489 (1 male), DA2/99/79, 2.6 n. mls WNW of W point of Kendrew I. $\left(20^{\circ} 27.64\right.$ 'S, $116^{\circ} 29.54^{\prime} \mathrm{E}$ to $20^{\circ} 27.25^{\prime} \mathrm{S}, 116^{\circ} 29.33^{\prime} \mathrm{E}$ ), rake box dredge, 38.0 m, 25.07.99; WAM C 29537 (1 male, 1 female ovig.), DA2/99/84; $2.9 \mathrm{n}$ mls $\mathrm{E}$ of Tish $\mathrm{Pt}$, Rosemary I. $\left(20^{\circ} 29.94 ' \mathrm{~S}, 116^{\circ} 38.11^{\prime} \mathrm{E}\right.$ to $20^{\circ} 29.84^{\prime} \mathrm{S}$, $\left.116^{\circ} 38.64^{\prime} \mathrm{E}\right)$, rake box dredge, $12.5-15.0 \mathrm{~m}, 26.07 .99$.

\section{Previous reported range}

Madagascar, Philippines, Indonesia, Japan; in Australia, in Western Australia between Shark Bay and Bedout Island, and in eastern Australia from Thursday Island, Torres Straits, and between Cairns and Stradbroke Island, Queensland (Banner and Banner, 1982; Chace, 1988; Nomura and Asakura, 1998).

\section{Depth range and habitat}

Subtidal to $130 \mathrm{~m}$. The specimens from the 
Dampier Archipelagenere taken at depths of 12.5$38 \mathrm{~m}$, amongst rocks, sand, sponges, corals, soft corals and other invertebrates.

\section{Colour in life}

Not reported.

\section{Alpheus rapacida De Man, 1908}

\section{Material examined}

Western Australia, Dampier Archipelago. WAM C 29497 (1 male), DA2/99/17, 3. n. mls ESE of Sloping Pt, Burrup Pen. (2032.995, $116^{\circ} 54.71$ 'E to $20^{\circ} 33.47^{\prime} S, 11654.97^{\prime} \mathrm{E}$ ), rake box dredge, 16.5-17.0 m, 16.07.99; WAM C 3356 (1 female ovig.), DA2/99/34, $3.3 \mathrm{n} . \mathrm{mls}$ NE of Courtenay Head Light, Malus I. (20 32.65'S, $116^{\circ} 39.14^{\prime} \mathrm{E}$ to $20^{\circ} 32.72^{\prime} \mathrm{S}, 116^{\circ} 39.59^{\prime} \mathrm{E}$ ), rake box dredge, 9.0-13.0 m, 19.07.99; WAM C 3360 (1 indet.), DA2/99/61, $2.85 \mathrm{n}$. m/s NW of Phillip Pt, Burrup Pen. (2035.33's, $116+2.78^{\prime} \mathrm{E}$ to $2034.83 \mathrm{~S}, 11642.91^{\prime} \mathrm{F}$ ), rake box dredge, $11.0 \mathrm{~m}$, 22.07.99; WAM C 33667 (1 female ovig.), DA2/ $99 / 68 ;-3.6$ n. $\mathrm{mls} S$ of Bluff Pt., Enderby I. (20.40.93's, $11633.21^{\circ} \mathrm{E}$ to $20^{\circ} 40.63^{\prime} \mathrm{S}$, $116 \% 33.36 \mathrm{E})$, rake box dredge, 9.0-9.2 m, 23.07.88; WAM C 33668 (1 male), DA3/99/62, East Lewis 1. (2037.499'S, $\left.11639.182^{\prime} \mathrm{E}\right)$, intertidal, 05.09.99.

\section{Previous reported range}

Mediterranean coast of Israel, the Red Sea, South Africa, Singapore, Thailand, Vietnam, Indonesia, Japan, Hawaii; in Australia from Western Australia to Yamba, New South Wales (Banner and Banner, 1982; Nomura and Asakura, 1998).

\section{Depth range and habitat}

Intertidal to $56 \mathrm{~m}$, in mud and sand. The specimens from the Dampier Archipelago were taken from the shore to a depth of $17 \mathrm{~m}$, amongst sand, mud and gravel.

\section{Colour in life}

Almost transparent with widely dispersed red stellate chromatophores; lateral margins of carapace with shifting band of rainbow colours, anterior portion of carapace with lemon-green pigment spots. Eyes pale violet. When living specimen twisted in light, whole animal displays delicate iridescence (Banner and Banner, 1982).

\section{Additional notes}

Banner and Banner (1982) reported that a gobs, Psilogobius mainlandi, lives in association with this shrimp.

\section{Alpheus serenei Tiwari, 1963 \\ Material examined \\ Western Australia, Dampier Archipelago. WAM} C 29454 (1 female), DA2/99/06, $2.7 \mathrm{n}$. mls ESF of C. Legendre (20)21.69's, 11652.40$)^{\circ} \mathrm{F}$ to $2021.23^{\prime} \mathrm{S}$, $11652.36 \mathrm{~F})$, rake box dredge, 33.0-36.0 m, 14.07.99; WAM C 29478 ( 1 temale ovig.), DA2/99/06, $2.7 \mathrm{n}$. $\mathrm{mls}$ ESE of C. Legendre $\left(20^{\circ} 21.69^{\prime} \mathrm{S}, 11652.40^{\prime} \mathrm{E}\right.$ to $20^{\circ} 21.23^{\prime} \mathrm{S}, 116^{\circ} 52.36^{\circ} \mathrm{E}$ ), rake box dredge, 33.0-36.0 m, 14.07.99; WAM C 29509 (1 male, 1 female ovig.), DA2/99/08, $3.6 \mathrm{n} \mathrm{mls} \mathrm{NNE} \mathrm{of} \mathrm{NW} \mathrm{point} \mathrm{of}$ Delambre I. $\left(20^{\circ} 22.76^{\prime} \mathrm{S}, 117^{\circ} 02.23^{\prime} \mathrm{E}\right.$ to $20^{\circ} 23.12^{\prime} \mathrm{S}$, $117^{\circ} 02.14^{\circ} \mathrm{E}$ ), rake box dredge, $30.0-31.0 \mathrm{~m}, 15.07 .99$; WAM C 29494 (1 male, 2 females ovig., 3 indet.), DA2/99/09, $5.5 \mathrm{n} \mathrm{mls} \mathrm{N}$ of $\mathrm{NE}$ corner of Delambre I. $\left(20^{\circ} 20.38^{\prime} \mathrm{S}, 117^{\circ} 05.22^{\prime} \mathrm{E}\right.$ to $\left.20^{\circ} 20.68^{\prime} \mathrm{S}, 117^{\circ} 05.63^{\prime} \mathrm{E}\right)$, rake box dredge, 31.0-34.5 m, 15.07.99; WAM C 29523 (2 males, 1 female ovig.), DA2/99/10, $1.9 \mathrm{n}$ $\mathrm{mls} \mathrm{N}$ of $\mathrm{NE}$ point of Delambre I. $\left(20^{\circ} 23.97^{\prime} \mathrm{S}\right.$, $117^{\circ} 04.82^{\prime} \mathrm{E}$ to $20^{\circ} 23.72^{\prime} \mathrm{S}, 117^{\circ} 04.70^{\prime} \mathrm{E}$ ), rake box dredge, 29.0 m, 15.07.99; WAM C 29488 (1 male),

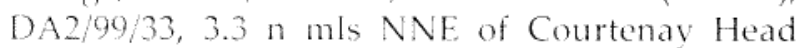
Light, Malus I. $\left(20^{\circ} 27.41^{\prime} \mathrm{S}, 116^{\circ} 42.57^{\prime} \mathrm{E}\right.$ to $20^{\circ} 27.33^{\prime} \mathrm{S}$, $116^{\circ} 43.05^{\prime} \mathrm{E}$ ), rake box dredge, $18.0-21.0 \mathrm{~m}, 18.07 .99$; WAM C 29468 (1 indet.), DA2/99/42, 2.4 n. mls SW of SW point of Goodwyn I. (2034.16'S, $11630.11^{\prime} \mathrm{E}$ to $\left.20^{\circ} 33.67^{\prime} \mathrm{S}, 116^{\circ} 30.01^{\prime} \mathrm{E}\right)$, rake box dredge, $14.0-16.0 \mathrm{~m}, 20.07 .99$; WAM C 29449 (1 male, 1 female ovig.), DA2/99/50, $6.5 \mathrm{n}$. mls $\mathrm{W}$ of Rocky Head, Enderby I. (20 37.10'S, $116^{\circ} 20.99^{\prime} \mathrm{E}$ to $\left.2037.28 \mathrm{~S}, 11621.08^{\prime} \mathrm{E}\right)$, rake box dredge, 24.0-25.0 m, 20.07.99; WAM C 29510 (2 males, 2 females ovig.), DA2/99/58, 1 n. mile NNE of Roly Rock (20²9.11'S, $116^{\circ} 30.78^{\prime} \mathrm{E}$ to $\left.20^{\circ} 29.35^{\prime} \mathrm{S}, 116^{\circ} 30.55^{\prime} \mathrm{E}\right)$, rake box dredge, $25.0-25.5 \mathrm{~m}, 21.07 .99$; WAM C 29492 (1 male, 2 females ), DA2/99/65, $2.4 \mathrm{n}$. mls NW of light on East Intercourse I. (2038.31'S, $116^{\circ} 38.46^{\prime} \mathrm{E}$ to $20^{\circ} 38.77^{\prime} \mathrm{S}, 116^{\circ} 38.54^{\prime} \mathrm{E}$ ), rake box dredge, 10.0-15.0 m, 23.07.99; WAM C 29547 (1 male, 1 female), DA2/99/68; $-3.6 \mathrm{n}$. mls $S$ of Bluff Pt, Enderby I. $\left(20^{\circ} 40.93^{\prime} \mathrm{S}, 116^{\circ} 33.21^{\prime} \mathrm{E}\right.$ to $20^{\circ} 40.63^{\prime} \mathrm{S}$,

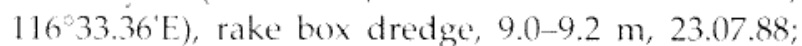
WAM C 29460 ( 1 female), DA2/99/75, $-0.75 \mathrm{n} . \mathrm{mls}$ E of NE point of Goodwyn 1. (20 32.16'S, $11633.70^{\prime} \mathrm{E}$ to $2031.70^{\prime} \mathrm{S}, 11633.20^{\prime} \mathrm{E}$ ), rake box dredge, 14.0 $19.0 \mathrm{~m}, 25.07 .88$; WAM C 29466 (1 male, 1 female ovig.), DA2/99/75, $-0.75 \mathrm{n} . \mathrm{m} / \mathrm{s} F$ of $\mathrm{NE}$ point of Goodwon I. (20 32.16's, $116^{\circ} 33.70^{\prime} \mathrm{E}$ to $20^{\circ} 31.70^{\prime} \mathrm{S}$, 116 33.20'E), rake box dredge, 14.0-19.0 m, 25.07.88; WAM C 29493 (1 female ovig.), DA2/99/75, 0 0.75 n. mls F of NE point of Goodwyn 1. (2032.16's, $11633.70^{\prime} \mathrm{E}$ to $2031.70^{\prime} \mathrm{S}, 11633.20 \mathrm{~F}$ ), rake box dredge, 14.0-19.0 m, 25.07.88; WAM C 29485 (1 male, 1 female ovig., 1 indet.), DA2/99/82, $1.2 \mathrm{n} \mathrm{mls}$ $N$ of $N$ point of Kendrew 1. $\left(2027.57 \mathrm{~S}, 11632.35^{\prime} \mathrm{F}\right.$ to $20^{\circ} 27.18^{\prime} \mathrm{S}, 11632.29^{\circ} \mathrm{E}$ ), rake box dredge, $32.0-$ $36.0 \mathrm{~m}, 25.07 .99$; WAM C 29548 (1 male), DA2/99/ $84,2.9 \mathrm{n} \mathrm{m} / \mathrm{s}$ E of Tish Pt, Rosemary I. (2029.94's, $11638.11 \mathrm{~F}$ to $2029.84 \mathrm{~S}, 11638.64 \mathrm{E})$, rake box 
dredge, 12.5-15.0 m, 26.07.99; WAM C 29515 (1 male, 3 females, 1 indet.), DA2/99/95, $1.1 \mathrm{n} . \mathrm{mls} W$ of Bluff Pt $\left(20^{\circ} 37.37^{\prime} \mathrm{S}, 116^{\circ} 31.69^{\prime} \mathrm{E}\right.$ to $20^{\circ} 37.45^{\prime} \mathrm{S}$, $\left.116^{\circ} 31.58^{\prime} \mathrm{E}\right), 5.0-7.0 \mathrm{~m}, 27.07 .99$; WAM C 29538 (1 female ovig.), DA2/99/99; $1.5 \mathrm{n}$. mls $W$ of Rocky Head, Enderby I. $\left(20^{\circ} 36.98^{\prime} \mathrm{S}, 116^{\circ} 26.25^{\prime} \mathrm{E}\right.$ to $\left.20^{\circ} 36.99^{\prime} \mathrm{S}, 116^{\circ} 26.36^{\prime} \mathrm{E}\right), 18.0-19.0 \mathrm{~m}, 28.07 .99$; WAM C 29549 (1 female ovig.) DA3/99/45, Rosemary I. $\left(20^{\circ} 29.671^{\prime} \mathrm{S}, 116^{\circ} 35.894^{\prime} \mathrm{E}\right)$, intertidal, 30/08/99; WAM C 27759 (2 females), DA3/99/56, Eaglehawk I., $\left(20^{\circ} 38.985 ' \mathrm{~S}, 116^{\circ} 26.210^{\prime} \mathrm{E}\right), 2.0-11.0$ m, 03/09/99; WAM C 28079 (1 female), DA3/99/56, Eaglehawk I., $\left(20^{\circ} 38.985^{\prime} \mathrm{S}, 116^{\circ} 26.210^{\prime} \mathrm{E}\right), 2.0-11.0$ m, 03/09/99.

\section{Previous reported range}

The Red Sea, eastern Africa, Indonesia, Singapore, Gulf of Thailand, Vietnam, Philippines, Japan; in Australia, from Broome, Western Australia across northern Australia to the Torres Straits (Banner and Banner, 1982; Chace, 1988; Nomura and Asakura, 1998).

\section{Depth range and habitat}

Amongst corals, to a depth of $62 \mathrm{~m}$; may be associated with an ophiuroid, Macrophiothrix longipeda (Banner and Banner, 1982; Chace, 1988). The specimens from the Dampier Archipelago were collected from the intertidal zone to a depth of $36 \mathrm{~m}$ amongst sand, rocks and corals. Most of the specimens were collected at depths greater than $10 \mathrm{~m}$.

\section{Colour in life}

Not reported.

\section{Alpheus spongiarum Coutière, 1897}

\section{Material examined \\ Western Australia, Dampier Archipelago. WAM} C 25641 (1 indet.), DA1/99/04, Legendre I. (20²4.320'S, $\left.116^{\circ} 56.108^{\prime} \mathrm{E}\right), 12.0-18.0 \mathrm{~m}, 18.10 .98$; WAM C 25913 (1 female ovig.), DA1/98/13, Hamersley Shoal $\left(20^{\circ} 23.203^{\prime} \mathrm{S}, 116^{\circ} 46.691^{\prime} \mathrm{E}\right), 1.0_{-}$ $16.0 \mathrm{~m}, 21.10 .98$; WAM C 33607 (1 male), DA2/99/ $04,4 \mathrm{n} . \mathrm{mls}$ NNW of Cohen I. $\left(20^{\circ} 19.64^{\prime} \mathrm{S}\right.$, $116^{\circ} 45.75^{\prime} \mathrm{E}$ to $\left.20^{\circ} 19.82^{\prime} \mathrm{S}, 116^{\circ} 45.98^{\prime} \mathrm{E}\right)$, rake box dredge, 42.0-43.0 m, 14.07.99; WAM C 29521 (6 females, 1 indet.), DA2/99/10, $1.9 \mathrm{n} \mathrm{mls} \mathrm{N}$ of $\mathrm{NE}$ point of Delambre I. $\left(20^{\circ} 23.97^{\prime} \mathrm{S}, 117^{\circ} 04.82^{\prime} \mathrm{E}\right.$ to $20^{\circ} 23.72^{\prime} \mathrm{S}, 117^{\circ} 04.70^{\prime} \mathrm{E}$ ), rake box dredge, $29.0 \mathrm{~m}$, 15.07.99; WAM C 33608 (2 females), DA2/99/10, 1.9 $\mathrm{n} \mathrm{mls} \mathrm{N}$ of $\mathrm{NE}$ point of Delambre I. (20.23.97'S, $117^{\circ} 04.82^{\prime} \mathrm{E}$ to $20^{\circ} 23.72^{\prime} \mathrm{S}, 117^{\circ} 04.70^{\prime} \mathrm{E}$ ), rake box dredge, 29.0 m, 15.07.99; WAM C 29503 (1 male, 2 females ovig.), DA2/99/12, $5.9 \mathrm{n} \mathrm{mls} \mathrm{NNW}$ of NW point of Delambre I. $\left(20^{\circ} 20.75^{\prime} \mathrm{S}, 117^{\circ} 01.16^{\prime} \mathrm{E}\right.$ to $\left.20^{\circ} 20.19^{\prime} \mathrm{S}, 117^{\circ} 01.18^{\prime} \mathrm{E}\right)$, rake box dredge, $32.0-34.0$ m, 15.07.99; WAM C 33609 (1 female), DA2/99/37, $2.5 \mathrm{n} \mathrm{mls}$ WNW of Marks Pt, West Lewis 1. $\left(20^{\circ} 36.54^{\prime} \mathrm{S}, 116^{\circ} 34.98^{\prime} \mathrm{E}\right.$ to $\left.20^{\circ} 36.11^{\prime} \mathrm{S}, 116^{\circ} 35.02^{\prime} \mathrm{E}\right)$, rake box dredge, $14.0-15.0 \mathrm{~m}, 19.07 .99$; WAM C 33610 ( 1 female, DA2/99/39), 1 n. mile ENE of Bluff Pt, Enderby I. (20³7.05'S, $116^{\circ} 33.86^{\prime} \mathrm{E}$ to $20^{\circ} 37.56^{\prime} \mathrm{S}$, $\left.116^{\circ} 33.45^{\prime} \mathrm{E}\right)$, rake box dredge, $13.0-14.0 \mathrm{~m}, 19.07 .99$; WAM C 33611 (1 female, 1 female ovig.), DA2/99/ 70 , $4.6 \mathrm{n}$. mls SSW of Bluff Pt, Enderby I. $\left(20^{\circ} 41.45^{\prime} \mathrm{S}, 116^{\circ} 30.78^{\prime} \mathrm{E}\right.$ to $\left.20^{\circ} 41.27^{\prime} \mathrm{S}, 116^{\circ} 30.92^{\prime} \mathrm{E}\right)$, rake box dredge, $10.0 \mathrm{~m}, 24.07 .99 ;$ WAM C 33772 (1 female, 1 female ovig.), DA2/99/70, $4.6 \mathrm{n}$. mls SSW of Bluff Pt, Enderby I. $\left(20^{\circ} 41.45^{\prime} \mathrm{S}, 116^{\circ} 30.78^{\prime} \mathrm{E}\right.$ to $20^{\circ} 41.27^{\prime} \mathrm{S}, 116^{\circ} 30.92^{\prime} \mathrm{E}$ ), rake box dredge, $10.0 \mathrm{~m}$, 24.07.99; WAM C 33612 (1 female ovig.), DA2/99/ $75, \sim 0.75 \mathrm{n}$. mls $\mathrm{E}$ of NE point of Goodwyn I. ( $20^{\circ} 32.16^{\prime} \mathrm{S}, 116^{\circ} 33.70^{\prime} \mathrm{E}$ to $\left.20^{\circ} 31.70^{\prime} \mathrm{S}, 116^{\circ} 33.20^{\prime} \mathrm{E}\right)$, rake box dredge, $14.0-19.0 \mathrm{~m}, 25.07 .99$; WAM C 33613 ( 8 males, 1 female), DA2/99/75, $0.75 \mathrm{n}$. mls E of NE point of Goodwyn I. $\left(20^{\circ} 32.16^{\prime} \mathrm{S}, 116^{\circ} 33.70^{\prime} \mathrm{E}\right.$ to $\left.20^{\circ} 31.70^{\prime} \mathrm{S}, 116^{\circ} 33.20^{\prime} \mathrm{E}\right)$, rake box dredge, 14.0 19.0 m, 25.07.99; WAM C 33614 (1 male), DA2/99/ 77, $1.8 \mathrm{n}$. mls NW of NW point of Goodwyn I. $\left(20^{\circ} 30.57^{\prime} \mathrm{S}, 116^{\circ} 30.89^{\prime} \mathrm{E}\right.$ to $\left.20^{\circ} 30.49^{\prime} \mathrm{S}, 116^{\circ} 30.91^{\prime} \mathrm{E}\right)$, rake box dredge, $13.0-14.0 \mathrm{~m}, 25.07 .99$; WAM C 33615 (1 male, 2 females ovig.), DA2/99/82, $1.2 \mathrm{n}$ $\mathrm{mls} \mathrm{N}$ of $\mathrm{N}$ point of Kendrew I. $\left(20^{\circ} 27.57^{\prime} \mathrm{S}\right.$, $116^{\circ} 32.35^{\prime} \mathrm{E}$ to $20^{\circ} 27.18^{\prime} \mathrm{S}, 116^{\circ} 32.29^{\prime} \mathrm{E}$ ), rake box dredge, $32.0-36.0 \mathrm{~m}, 25.07 .99$; WAM C 33616 (3 females), DA2/99/95, $1.1 \mathrm{n}$. mls $\mathrm{W}$ of Bluff $\mathrm{Pt}$ $\left(20^{\circ} 37.37^{\prime} \mathrm{S}, 116^{\circ} 31.69^{\prime} \mathrm{E}\right.$ to $\left.20^{\circ} 37.45^{\prime} \mathrm{S}, 116^{\circ} 31.58^{\prime} \mathrm{E}\right)$, 5.0-7.0 m, 27.07.99; WAM C 33617 (1 male), DA2/ 99/99, 1.5 n. mls W of Rocky Head, Enderby I. $\left(20^{\circ} 36.98^{\prime} \mathrm{S}, 116^{\circ} 26.25^{\prime} \mathrm{E}\right.$ to $\left.20^{\circ} 36.99^{\prime} \mathrm{S}, 116^{\circ} 26.36^{\prime} \mathrm{E}\right)$, 18.0-19.0 m, 28.07.99;WAM C 28068 (1 male), DA3/ 99/42, Georgeff Reef (20²9.339'S, 116 $\left.36.798^{\prime} \mathrm{E}\right)$, intertidal, 28.08.99; WAM C 27755 ( 1 female), DA3/ 99/53, Enderby I. (20³4.528'S, $\left.116^{\circ} 34.575^{\prime} \mathrm{E}\right), 3.0-7.0$ m, 01.09.99; WAM C 33618 (1 male, 1 female ovig.), DA3/99/61, West Lewis I. (20³4.693'S, $\left.116^{\circ} 39.698^{\prime} \mathrm{E}\right), 3.0-5.0 \mathrm{~m}, 04.09 .99$; WAM C 33619 (1 indet.), West Lewis I. (20³6.658'S, $116^{\circ} 36.956$ ' E), 2.0-5.0 m, 06/09/99.

\section{Previous reported range}

Djibouti, Gulf of Aden, Maldives and Laccadive Archipelagoes, Sri Lanka, Singapore, Indonesia, Philippines, Japan; in Australia, from Western Australia across to Heron Island, Capricorn Group, Queensland (Banner and Banner, 1982; Chace, 1988).

\section{Depth range and habitat}

Under corals or in sponges; intertidal to a depth of $42 \mathrm{~m}$ (Banner and Banner, 1982; Chace, 1988). The specimens from the Dampier Archipelago were taken from the intertidal zone to a depth of $43 \mathrm{~m}$, amongst sand, rocks, coral and sponges. 


\section{Colour in life}

Mostly translucent, chelipeds dark to light red, abdominal segments banded with red (Banner and Banner, 1982).

\section{Additional notes}

The ovigerous female from station DA2/75 was parasitized by an epicaridean isopod.

\section{Alpheus strenuus strenuus Dana, 1852}

\section{Material examined}

Western Australia, Dampier Archipelago. WAM C 25647 (1 male), DA1/98/35, Legendre I. $\left(20^{\circ} 23.620^{\prime} \mathrm{S}, 116^{\circ} 51.960^{\prime} \mathrm{E}\right), 0.0-1.0 \mathrm{~m}, 29.10 .98$; WAM C 27733, (1 male, 2 female ovig.), DA3/99/38, Malus Is $\left(20^{\circ} 30.632^{\prime} \mathrm{S}, 116^{\circ} 38.788^{\prime} \mathrm{E}\right)$, intertidal, 27.08.99; WAM C 28100, (1 male, 1 female ovig.), DA3/99/38, Malus Is $\left(20^{\circ} 30.632^{\prime} \mathrm{S}, 116^{\circ} 38.788^{\prime} \mathrm{E}\right)$, intertidal, 27.08.99; WAM C 27765 (1 male, 1 female ovig.), DA3/99/62, East Lewis I. (20³7.499's, $\left.116^{\circ} 39.182^{\prime} \mathrm{E}\right)$, intertidal, 05.09.99.

\section{Previous reported range}

Throughout the Indo-Pacific area from the Red Sea to the Society Islands; in Australia, from Dampier, Western Australia, across northern Australia to Sydney, New South Wales (Banner and Banner, 1982); not Galapagos Islands (misidentification of $A$. galapagensis Sivertsen, see McClure and Wicksten, 2000).

\section{Depth range and habitat}

Lower intertidal zone, under rocks on sandy beaches (Banner and Banner, 1982). The specimens from the Dampier Archipelago were taken from the intertidal zone to a depth of $1 \mathrm{~m}$, amongst corals, silt, sand, sand and rocks.

\section{Colour in life}

Variable: green-yellow to green-brown, with some white markings or stripes on carapace and abdomen, hands mottled with large areas of olive green and white, hands orange with irregular patches of dark gray (Banner and Banner, 1982). See photos in Kamezaki et al. (1988: 63) and Jones and Morgan (2002: 65).

\section{Additional notes}

All of the specimens from the Dampier Archipelago agree with the description of the typical subspecies of $A$. strenuus.

\section{Alpheus sulcatus Kingsley, 1878}

\section{Material examined}

Western Australia, Dampier Archipelago. WAM
C 33636 (1 male, 1 female ovig.), DA3/99/45, Rosemary I. (20029.671'S, $11635.894 ' \mathrm{E})$, intertidal, 30/08/99; WAM C 27750 (1 male, 1 female ovig.), DA3/99/48, Goodwyn I. (2032.000'S, $\left.116^{\circ} 32.420^{\prime} \mathrm{E}\right)$, intertidal, $31 / 08 / 99$.

\section{Previous reported range}

Gulf of Philippines, Indonesia, Japan, Society Islands; eastern and western coasts of Australia; eastern Pacific from Gulf of California to Peru (Banner and Banner, 1982; Wicksten, 1983; Chace, 1988).

\section{Depth range and habitat}

Intertidal to $24 \mathrm{~m}$, amongst rocks and corals (Chace, 1988). The specimens from the Dampier Archipelago were taken amongst intertidal rocks.

\section{Colour in life}

Dark green with mottling on hands (Yaldwyn, in Banner and Banner, 1982). Specimens from the Gulf of California were dark red with black tips to the fingers of the major chela (Kerstitch, 1989). A photograph in Kamezaki et al. (1988: 64) shows a red individual with a pale mid-dorsal stripe.

\section{Additional notes}

This species has been observed by one of us (MKW) in the intertidal zone near Guaymas, Gulf of California. It commonly lives in male-female pairs under rocks.

\section{Alpheus tasmanicus? Banner and Banner, 1982}

\section{Material examined}

Western Australia, Dampier Archipelago. WAM C 27764 (1 female), DA3/99/62, East Lewis I. (20⒊499'S, 116 $\left.39.182^{\prime} \mathrm{E}\right)$, intertidal, 05.09.99.

\section{Previous reported range \\ "Tasmania" (Banner and Banner, 1982).}

\section{Depth range and habitat}

Not reported. The specimen from East Lewis Island was taken intertidally in a bay with mangroves, sand and mud and a rocky foreshore.

\section{Colour in life}

Not reported.

\section{Additional notes}

The specimen is missing one chela, but appears more similar to the description of A.tasmanicus than to other alpheids of the Edwardsii group known from Australia. Without being able to compare the specimen with the holotype of A. tasmanicus, we cannot be certain of the identification. 


\section{Alpheus villosus (Olivier, 1811)}

Material examined

Western Australia, Dampier Archipelago. WAM C 29480 (1 male), DA2/99/50, 6.5 n. mls $W$ of Rocky Head, Enderby I (20 37.10'S, $11620.99^{\prime} \mathrm{E}$ to $\left.20^{\circ} 37.28^{\prime} \mathrm{S}, 116^{\circ} 21.08^{\prime} \mathrm{E}\right)$, rake box dredge, 24.0-25.0 m, 20.07.99; WAM C 29474 (1 male, 1 female), DA2/ 99/58; $1 \mathrm{n}$. mile NNE of Roly Rock $\left(20^{\circ} 29.11\right.$ 's, $116^{\circ} 30.78^{\prime} \mathrm{E}$ to $20^{\circ} 29.35^{\prime} \mathrm{S}, 116^{\circ} 30.55^{\prime} \mathrm{E}$ ), rake box dredge, 25.0-25.5 m, 21.07.99; WAM C 29469 (2 males, 1 female, 1 female ovig.), DA2/99/99, 1.5 n. $\mathrm{mls} W$ of Rocky Head, Enderby 1. (2036.98'S, $116^{\circ} 26.25^{\prime} \mathrm{E}$ to $\left.20^{\circ} 36.99^{\prime} \mathrm{S}, 116^{\circ} 26.36^{\prime} \mathrm{E}\right), 18.0-19.0 \mathrm{~m}$, 28.07.99; WAM C 27731 (1 female ovig.), DA3/99/ 37 . Malus Is $\left(20^{\circ} 30.632^{\prime} \mathrm{S}, 116^{\circ} 38.788^{\prime} \mathrm{E}\right), 2.0-3.5 \mathrm{~m}$, 27.08 .99

\section{Previous reported range}

South Africa, Mascarene Island, Sulu Sea, Philippines; in Australia from Perth, Western Australia to Twofold Bay, New South Wales, and Exmouth Gulf, Western Australia to Torres Straits (Banner and Banner, 1982).

\section{Depth range and habitat}

Intertidal to $44 \mathrm{~m}$, in coral (Chace, 1988). The specimens from the Dampier Archipelago were collected at depths of 2 to $25 \mathrm{~m}$, amongst rock, shells, corals, sponges, rubble and other marine invertebrates.

\section{Colour in life}

Lemon yellow to pale light orange with stellate red chromatophores, red and white striped antennules and antennae and red eyes; mesial face of large chela bright orange, dorsal spines of telson and posterior lateral spines orange (Banner and Banner, 1981). See photograph in Debelius (1999: 149).

\section{Additional notes}

Banner and Banner (1982) distinguished between a "northern" and a "southern" form of this species on the basis of the armature of the merus and carpus of the third pereopods. As of this writing, no one has formally designated these forms as separate subspecies or species.

\section{Synalpheus Bate, 1888}

\section{Synalpheus ancistrorhynchus De Man, 1909}

\author{
Material examined \\ Western Australia, Dampier Archipelago. WAM \\ C 25957 (1 female ovig.), DA1/98/01, Dolphin I. \\ $\left(20^{\circ} 25.852^{\prime} \mathrm{S}, 116^{\circ} 52.953^{\prime} \mathrm{E}\right), 3.0-6.5 \mathrm{~m}, 17 / 09 / 98$; \\ WAM C 25309 (20 indet.), DA1/98/11, Dolphin I \\ $\left(20^{\circ} 30.249^{\prime} \mathrm{S}, 116^{\circ} 49.335^{\prime} \mathrm{E}\right)$, intertidal, 21.10.98;
}

WAM C 25817 (1 female ovig.), Angel I $\left(20^{\circ} 30.200^{\prime} \mathrm{S}, 116^{\circ} 47.250^{\prime} \mathrm{E}\right), 2.0-7.0 \mathrm{~m}, 21.10 .98$ WAM C 25656 (1 indet.), DA1/98/34, Tozer I $\left(20^{\circ} 27.684^{\prime} \mathrm{S}, 116^{\circ} 50.486^{\prime} \mathrm{E}\right)$, intertidal, 29.10.98; WAM C 25910 (1 male), DA1/98/34, Tozer I. $\left(20^{\circ} 27.684^{\prime} \mathrm{S}, 116^{\circ} 50.486 \mathrm{E}\right)$, intertidal, 29.10.98; WAM C 33072 (1female, 1 indet.), DA1/98/34, Tozer I. $\left(20^{\circ} 27.684^{\prime} \mathrm{S}, 116^{\circ} 50.486^{\prime} \mathrm{E}\right)$, intertidal, 29.10 .98 ; WAM C 29455 (2 females, 6 indet.), DA2/9937, 2.5 n mls WNW of Marks Pt, West Lewis I. (20 $36.54^{\prime} \mathrm{S}$, $116^{\circ} 34.98^{\prime} \mathrm{E}$ to $\left.20^{\circ} 36.11 \mathrm{~S}, 116^{\circ} 35.02^{\prime} \mathrm{E}\right)$, rake box dredge, 14.0-15.0 m, 19/07/99; WAM C 29550 (2 males, 1 female, 1 indet.), DA2/99/70, $4.6 \mathrm{n}$. mls SSW of Bluff Pt, Enderby I. $\left(20^{\circ} 41.45^{\prime} \mathrm{S}, 116^{\circ} 30.78^{\prime} \mathrm{E}\right.$ to $20^{\circ} 41.27^{\prime} \mathrm{S}, 116^{\circ} 30.92 \mathrm{E}$ ), rake box dredge, $10.0 \mathrm{~m}$, 24.07.99; WAM C 33775 (1 female), DA2/99/95, 1.1 n. mls $W$ of Bluff Pt $\left(20^{\circ} 37.37^{\prime} S, 116^{\circ} 31.69^{\prime} \mathrm{E}\right.$ to $\left.20^{\circ} 37.45^{\prime} \mathrm{S}, 116^{\circ} 31.58^{\prime} \mathrm{E}\right), 5.0-7.0 \mathrm{~m}, 27.07 .99$; WAM C 33776 (1 female), DA2/99/99, $-1.5 \mathrm{n}$. mls $\mathrm{W}$ of Rocky Head, Enderby 1. (20 36.98'S, $116^{\circ} 26.25^{\prime} \mathrm{E}$ to 20'36.99'S, $\left.116^{\circ} 26.36^{\prime} \mathrm{E}\right), 18.0-19.0 \mathrm{~m}, 28.07 .99 ; \mathrm{WAM}$ C 33778 (1 female ovig., 3 indet.), DA3/99/42, Georgeff Reef $\left(20^{\circ} 29.339^{\prime} \mathrm{S}, 116^{\circ} 36.798^{\prime} \mathrm{E}\right)$, intertidal, 28.08.99; WAM C 33779 (4 indet.), DA3/99/47, Kendrew I. $\left(20^{\circ} 29.671 \mathrm{~S}, 116^{\circ} 32.519^{\prime} \mathrm{E}\right), 4.0-5.0 \mathrm{~m}$, 30.08.99, WAM C 27774 (1 indet.), DA3/99/70, Nelson Rocks $\left(20^{\circ} 27.441^{\prime} \mathrm{S}, 116^{\circ} 39.588^{\prime} \mathrm{E}\right), 5.0-7.0 \mathrm{~m}$, 08.09 .99 .

\section{Previous reported range}

Indonesia; in Australia, Western Australia, and off Queensland (Banner and Banner, 1975).

\section{Depth range and habitat}

To $38 \mathrm{~m}$, amongst coral heads (Banner and Banner, 1975). The specimens from the Dampier Archipelago were taken intertidally to a depth of 19 $\mathrm{m}$, amongst rocks, corals, gorgonians, silty areas and other mixed habitats.

\section{Colour in life}

Not reported.

\section{Additional notes}

One individual from station DA2/37 was parasitized by an epicardean isopod.

\section{Synalpheus bispinosus De Man, 1910}

\section{Material examined}

Western Australia, Dampier Archipelago. WAM C 33355 (1 female), DA2/99/73, 24.07.99; $3.25 \mathrm{n} \mathrm{mls}$ S of Rocky Head, Enderby I. (20 $40.14^{\prime} S, 116^{\circ} 27.69^{\prime} \mathrm{E}$ to $20^{\circ} 39.93^{\prime} \mathrm{S}, 116^{\circ} 27.96^{\prime} \mathrm{E}$ ), rake box dredge, $12.5 \mathrm{~m}$, 24.07 .99 .

\section{Previous reported range}

The Red Sea, Indonesia, southern Philippines; in 
Australia, from the Dampier Archipelago (Western Australia), Darwin (Northern Territory) and the Torres Straits (Banner and Banner, 1975).

\section{Depth range and habitat}

Between depths of $2-31 \mathrm{~m}$, habitat not recorded (Banner and Banner, 1975). The specimen from the Dampier Archipelago was taken at a depth of 12.5 $\mathrm{m}$, amongst sand, rocks, sponges and corals.

\section{Colour in life}

Not reported

\section{Synalpheus comatulorum (Haswell, 1882)}

\section{Material examined}

Western Australia, Dampier Archipelago. WAM C 29501 (1 female), DA2/99/06, $2.7 \mathrm{n}$. mls ESE of C. Legendre $\left(20^{\circ} 21.69^{\prime} \mathrm{S}, 116^{\circ} 52.40^{\prime} \mathrm{E}\right.$ to $20^{\circ} 21.23^{\prime} \mathrm{S}$, $\left.116^{\circ} 52.36^{\prime} \mathrm{E}\right)$, rake box dredge, $33.0-36.0 \mathrm{~m}, 14.07 .99$; WAM C 29527 (1 female), DA2/99/07, 6.5 n. mls almost $\mathrm{E}$ of $\mathrm{C}$. Legendre $\left(20^{\circ} 20.90^{\prime} \mathrm{S}, 116^{\circ} 57.04^{\prime} \mathrm{E}\right.$ to $\left.20^{\circ} 20.98^{\prime} \mathrm{S}, 116^{\circ} 56.79^{\prime} \mathrm{E}\right)$, rake box dredge, $37.0 \mathrm{~m}$, 15.07.99; WAM C 33637 (1 female, 1 female ovig.), DA2/99/09, $~ 5.5 \mathrm{n} \mathrm{mls} \mathrm{N}$ of $\mathrm{NE}$ corner of Delambre I. $\left(20^{\circ} 20.38^{\prime} \mathrm{S}, 117^{\circ} 05.22^{\prime} \mathrm{E}\right.$ to $\left.20^{\circ} 20.68^{\prime} \mathrm{S}, 117^{\circ} 05.63^{\prime} \mathrm{E}\right)$, rake box dredge, $31.0-34.5 \mathrm{~m}, 15.07 .99$; WAM C 29524 (1 male, 1 female ovig.), DA2/99/18, $5 \mathrm{n}$. mls SE of Sloping Pt, Burrup Pen. (20³5.67'S, $116^{\circ} 54.97^{\prime} \mathrm{E}$ to $20^{\circ} 36.12^{\prime} \mathrm{S}, 116^{\circ} 55.09^{\prime} \mathrm{E}$ ), rake box dredge, 10.0-10.5 m, 16.07.99; WAM C 33638 (1 female ovig.), DA2/99/41, $1.3 \mathrm{n}$. mls $\mathrm{N}$ of Rocky Head, Enderby I. $\left(20^{\circ} 35.635,116^{\circ} 28.07^{\prime} \mathrm{E}\right.$ to $\left.20^{\circ} 35.09^{\prime} \mathrm{S}, 116^{\circ} 27.81^{\prime} \mathrm{E}\right)$, rake box dredge, 16.0-17.4 m, 20.07.99; WAM C 33639 (1 male), DA2/99/42, $2.4 \mathrm{n} . \mathrm{m} / \mathrm{s}$ SW of SW point of Goodwyn I., (20 34.16'S, $116^{\circ} 30.11^{\prime} \mathrm{E}$ to $\left.20^{\circ} 33.67^{\prime} \mathrm{S}, 116^{\circ} 30.01^{\prime} \mathrm{E}\right)$, rake box dredge, $14.0-16.0 \mathrm{~m}, 20.07 .99$; WAM C 33640 (1 female), DA2/99/50, $6.5 \mathrm{n} . \mathrm{mls} W$ of Rocky Head, Enderby I (20 37.10'S, $116^{\circ} 20.99^{\circ} \mathrm{E}$ to $20^{\circ} 37.28^{\prime} \mathrm{S}, 116^{\circ} 21.08^{\prime} \mathrm{E}$ ), rake box dredge, $24.0-25.0$ m, 20.07.99; WAM C 29471 (1 female), DA2/99/62, Flying Foam Passage, $0.9 \mathrm{n}$. mls NE of $\mathrm{S}$ point of Angel 1., $\left(20^{\circ} 30.69^{\prime} \mathrm{S}, 116^{\circ} 48.58^{\prime} \mathrm{E}\right.$ to $20^{\circ} 31.17^{\prime} \mathrm{S}$, $\left.116^{\circ} 48.33^{\prime} \mathrm{E}\right)$, rake box dredge, 7.0-9.0 m, 22.07.99; WAM C 29500 (1 female), DA2/99/62, Flying Foam Passage, $0.9 \mathrm{n}$. mls NE of $\mathrm{S}$ point of Angel I., $\left(20^{\circ} 30.69^{\prime} \mathrm{S}, 116^{\circ} 48.58^{\prime} \mathrm{E}\right.$ to $\left.20^{\circ} 31.17^{\prime} \mathrm{S}, 116^{\circ} 48.33^{\prime} \mathrm{E}\right)$, rake box dredge, $7.0-9.0 \mathrm{~m}, 22.07 .99$; WAM C 33641 (1 male), DA2/99/65, $2.4 \mathrm{n}$. mls NW of light on East Intercourse 1. $\left(20^{\circ} 38.31^{\prime} \mathrm{S}, 116^{\circ} 38.46^{\prime} \mathrm{E}\right.$ to $20^{\circ} 38.77^{\prime} \mathrm{S}, 11638.54^{\prime} \mathrm{E}$ ), rake box dredge, 10.0-15.0 m, 23.07.99; WAM C 29450 (1 female), DA2/99/68; $-3.6 \mathrm{n} . \mathrm{mls} \mathrm{S}$ of Bluff Pt., Enderby 1. $\left(20^{\circ} 40.93^{\mathrm{S}} \mathrm{S}\right.$, $116^{\circ} 33.21^{\prime} \mathrm{E}$ to $20^{\circ} 40.63^{\prime} \mathrm{S}, 116^{\circ} 33.36^{\circ} \mathrm{E}$ ), rake box dredge, 9.0-9.2 m, 23.07.88; WAM C 33642 (1 female ovig.), DA2/99/73, 24.07.99; $3.25 \mathrm{n} \mathrm{mls} \mathrm{S}$ of Rocky Head, Enderby I. $\left(20^{\circ} 40.14^{\prime} \mathrm{S}, 116^{\circ} 27.69^{\circ} \mathrm{F}\right.$ to $20^{\circ} 39.93^{\prime} \mathrm{S}, 11627.96^{\circ} \mathrm{E}$ ), rake box dredge, $12.5 \mathrm{~m}$, 24.07.99; WAM C 29502 (1 female), DA2/99/75, $-0.75 \mathrm{n} . \mathrm{m} / \mathrm{s} \mathrm{E}$ of $\mathrm{NE}$ point of Goodwyn I. (20 32.16 S, $11633.70 \mathrm{~F}$ to $2031.70 \mathrm{~S}, 116333.20^{\circ} \mathrm{E}$ ), rake box dredge, $14.0-19.0 \mathrm{~m}, 25.07 .99$.

\section{Previous reported range}

Sri Lanka, Singapore; eastern and western coasts of Australia (Banner and Banner, 1975).

\section{Depth range and habitat}

Subtidal, commensal with crinoids, including Comanthus timorensis and Comatula purpurea (Banner and Banner, 1975). The specimens from the Dampier Archipelago were dredged at depths of 7 $37 \mathrm{~m}$ in mixed bottoms of corals, rocks, sand and shell. No hosts were reported except for the female from station DA2/62, which was reported to be "on crinoid".

\section{Colour in life}

Colour dependent on that of host, capable of being changed by use of chromatophores; ranging from transparent to dark, usually with pigmented longitudinal stripes against transparent or white background (Potts, in Banner and Banner, 1975).

\section{Synalpheus coutierei Banner, 1953}

\section{Material examined}

Western Australia, Dampier Archipelago. WAM C 33780 (1 indet.), DA1/98/07, Gidley I. (20²8.010's, $\left.116^{\circ} 47.720^{\prime} \mathrm{E}\right), 0.0-2.0 \mathrm{~m}, 19.10 .98$; WAM C 25678 (1 female, 1 indet.), DA1/98/33; Angel I. $\left(20^{\circ} 27.965^{\prime}\right.$ S, $116^{\circ} 49.692^{\prime} \mathrm{E}$ ), 1.0-8.0 m, 29.10.98; WAM C 25909 (1 female ovig., 1 indet. [broken, species identification questionable]), DA1/98/35, Legendre I. (20 23.620'S, $\left.116^{\circ} 51.960^{\prime} \mathrm{E}\right), 0.0-1.0 \mathrm{~m}, 29.10 .98$; WAM C 25919 (1 female ovig., 1 indet.), DA1/98/35, Legendre I. $\left(20^{\circ} 23.620^{\circ} \mathrm{S}, 116^{\circ} 51.960^{\prime} \mathrm{E}\right), 0.0-1.0 \mathrm{~m}, 29.10 .98$; WAM C 33781 (1 female, 1 indet.), DA2/99/82, $1.2 \mathrm{n}$ mls $\mathrm{N}$ of $\mathrm{N}$ point of Kendrew I. $\left(20^{\circ} 27.57^{\prime} \mathrm{S}\right.$, $116^{\circ} 32.35^{\prime} \mathrm{E}$ to $20^{\circ} 27.18^{\prime} \mathrm{S}, 116^{\circ} 32.29^{\prime} \mathrm{E}$ ), rake box dredge, $32.0-36.0 \mathrm{~m}, 25.07 .99$.

\section{Previous reported range}

Suez Canal, the Persian Gulf south to Mozambique, and across Indo-Pacific but not including Hawaii or the Society Islands; In Australia, northwestern West Australia to Queensland. (Banner and Banner, 1975); Philippines, Indonesia (Chace, 1988). A record of this species from Clipperton Island is a misidentification of $S$. biunguiculatus (Stimpson) (Chace, 1988).

\section{Depth range and habitat}

Shallow water to $77 \mathrm{~m}$, in heads of dead coral, 
amongst sponges, in settling growth on buoys (Chace, 1988). The specimens from the Dampier Archipelago came from intertidal areas to a depth of $36 \mathrm{~m}$, amongst rocks, sand, algae, corals and other mixed habitat.

\section{Colour in life}

Not reported.

\section{Synalpheus fossor (Paulson, 1875)}

\section{Material examined}

Western Australia, Dampier Archipelago. WAM C 29543 (1 female ovig.), DA2/99/95, $1.1 \mathrm{n}$. mls W of Bluff $\mathrm{Pt}\left(20^{\circ} 37.37^{\prime} \mathrm{S}, 116^{\circ} 31.69^{\prime} \mathrm{E}\right.$ to $20^{\circ} 37.45^{\prime} \mathrm{S}$, $\left.116^{\circ} 31.58^{\prime} \mathrm{E}\right), 5.0-7.0 \mathrm{~m}, 27.07 .99$.

\section{Previous reported range}

The Red Sea, Maldive Archipelago, Indonesia, Thailand, Philippines; in Australia, from southwestern Australia across the northern coast to Kangaroo I., South Australia (Banner and Banner, 1975).

\section{Depth range and habitat}

To a depth of $50 \mathrm{~m}$, in dead coral and sponges (Banner and Banner, 1975; Chace, 1988). The specimen from DA2/95 was collected at a depth of 5-7 $\mathrm{m}$, amongst rock, corals, sponges and other invertebrates.

\section{Colour in life \\ Salmon pink (Banner and Banner, 1975).}

\section{Additional notes}

The specimen examined was peculiar in having four pairs of dorsolateral spines on the telson instead of two pairs.

\section{Synalpheus hastilicrassus Coutiére, 1905}

\section{Material examined}

Western Australia, Dampier Archipelago. WAM C 25807 (2 indet.), DA1/98/01, Dolphin I. $\left(20^{\circ} 25.852^{\prime} \mathrm{S}, 116^{\circ} 52.953^{\prime} \mathrm{E}\right), 3.0-6.5,17 / 09 / 98 ;$ WAM C 25700 (4 indet.), DA1/99/04, Legendre I. (20²4.320'S, $\left.116^{\circ} 56.108^{\prime} \mathrm{E}\right), 12.0-18.0 \mathrm{~m}, 18.10 .98$; WAM C 25700 (3 indet.), DA1/98/99/04, Legendre I. (20²4.320'S, 116 $\left.56.108^{\prime} \mathrm{E}\right), 12.0-18.0 \mathrm{~m}, 18.10 .98$; WAM C 25693 (1 female), DA1/98/13, Hamersley Shoal $\left(20^{\circ} 23.203^{\prime} \mathrm{S}, 116^{\circ} 46.691^{\prime} \mathrm{E}\right), 1.0-16.0 \mathrm{~m}$, 21.10.98; WAM C 25695 ( 2 indet., no minor chela, identification questionable), DA1/98/13, Hamersley Shoal $\left(20^{\circ} 23.203^{\prime} \mathrm{S}, 116^{\circ} 46.691^{\prime} \mathrm{E}\right), 1.0-16.0 \mathrm{~m}$, 21.10.98; WAM C 25895 (2 indet.), DA1/98/13, Hamersley Shoal $\left(20^{\circ} 23.203^{\prime} \mathrm{S}, 116^{\circ} 46.691 \mathrm{E}\right), 1.0$ $16.0 \mathrm{~m}, 21.10 .98$; WAM C 25907 (1 indet. [no minor chela, identification questionable]), DA1/98/31, Searipple Passage $\left(20^{\circ} 31.230^{\prime} \mathrm{S}, 116^{\circ} 51.182^{\prime} \mathrm{E}\right)$, intertidal, 28.10.98; WAM C 33782 (1 indet.), DA2/ $99 / 10,1.9 \mathrm{n} \mathrm{mls} \mathrm{N}$ of $\mathrm{NE}$ point of Delambre $\mathrm{I}$. $\left(20^{\circ} 23.97^{\prime} \mathrm{S}, 117^{\circ} 04.82^{\prime} \mathrm{E}\right.$ to $\left.20^{\circ} 23.72^{\prime} \mathrm{S}, 117^{\circ} 04.70^{\prime} \mathrm{E}\right)$, rake box dredge, $29.0 \mathrm{~m}, 15.07 .99 ;$ WAM C 29530 (1 female ovig.), DA2/99/13; - $2.25 \mathrm{n} \mathrm{mls}$ off Haüy I $\left(20^{\circ} 26.52^{\prime} \mathrm{S}, 117^{\circ} 00.50^{\prime} \mathrm{E}\right.$ to $\left.20^{\circ} 26.27^{\prime} \mathrm{S}, 117^{\circ} 00.56^{\prime} \mathrm{E}\right)$, rake box dredge, 19.5.m, 16.07.99; WAM C 33783 (2 females ovig.), DA2/99/65, $2.4 \mathrm{n}$. mls NW of light on East Intercourse 1. $\left(20^{\circ} 38.31^{\prime} \mathrm{S}, 116^{\circ} 38.46^{\prime} \mathrm{E}\right.$ to $20^{\circ} 38.77^{\prime} \mathrm{S}, 116^{\circ} 38.54^{\prime} \mathrm{E}$ ), rake box dredge, 10.0-15.0 m, 23.07.99; WAM C 33784 (2 females ovig., 2 indet.), DA2/99/95, 1.1 n. mls $W$ of Bluff $\mathrm{Pt}$ $\left(20^{\circ} 37.37^{\prime} \mathrm{S}, 116^{\circ} 31.69^{\prime} \mathrm{E}\right.$ to $\left.20^{\circ} 37.45^{\prime} \mathrm{S}, 116^{\circ} 31.58^{\prime} \mathrm{E}\right)$, 5.0-7.0 m, 27.07.99; WAM C 27736 (1 female ovig., 4 indet.), DA3/99/41, Georgeff Reefs (20²9.339'S, $\left.116^{\circ} 36.798^{\prime} \mathrm{E}\right), 1.0-4.0 \mathrm{~m}, 28-29.08 .99$; WAM C 27753 (4 indet.), DA3/99/52, Roly Rock (20²9.696'S, $\left.116^{\circ} 30.166^{\prime} \mathrm{E}\right), 9.0-26.0 \mathrm{~m}, 01 / 09 / 99$.

\section{Previous reported range}

Maldive Islands, Gulf of Manaar, Indonesia, Philippines, Japan, Caroline and Marshall Islands, Fiji; in Australia, Darwin, Northern Territory, and from the Torres Straits to south of Bundaberg, Queensland (Banner and Banner, 1975; Nomura and Asakura, 1998). These specimens are the first taken in northwestern Australia.

\section{Depth range and habitat}

Usually in depths of $5 \mathrm{~m}$ or less, but recorded to $90 \mathrm{~m}$; in sponges or coral heads (Banner and Banner, 1975). Specimens from the Dampier Archipelago were taken from the intertidal zone to a depth of 29 $\mathrm{m}$, amongst rocks, sand, algae, sponges and corals.

\section{Colour in life}

Not reported.

\section{Additional notes}

One specimen each from stations DA3/41 and DA3/52 were parasitized by rhizocephalan cirripedes. Chace (1988) provided additional information on variation in this species as well as illustrations.

\section{Synalpheus neomeris De Man, 1897}

\section{Material examined}

Western Australia, Dampier Archipelago. WAM C 25697 (2 indet.), DA1/98/04, Legendre I. (2024.320'S, $\left.116^{\circ} 56.108^{\prime} \mathrm{E}\right), 12.0-18.0 \mathrm{~m}, 18.10 .98$; WAM C 33620 (1 female ovig.), DA1/98/04, Legendre I. (2024.320'S, $\left.116^{\circ} 56.108^{\prime} \mathrm{E}\right), 12.0-18.0 \mathrm{~m}$, 18.10.98; WAM C 33621 (1 female), DA1/98/07, Gidley I. $\left(20^{\circ} 28.010^{\prime} \mathrm{S}, 116^{\circ} 47.720^{\prime} \mathrm{E}\right), 0.0-2.0 \mathrm{~m}$, 19.10.98; WAM C 27775 (2 females ovig.), DA1/98/ 
15, Legendre I. (20²1.142'S, $\left.11650.579^{\prime} \mathrm{E}\right), 5.0-29.0$ m, 22.10.98; WAM C 33622 (1 female, 1 female ovig., 4 indet.), DA1/98/30; Burrup Peninsula (20 $31.586^{\circ}$ S, $11651.088 \mathrm{E}), 1.0-10.0 \mathrm{~m}, 27.10 .98$; WAM C 25888 (1 female ovig., 1 indet.), DA1/99/32, Legendre I. $\left(20^{\circ} 23.520^{\prime} \mathrm{S}, 116^{\circ} 54.110^{\prime} \mathrm{E}\right), 5.0-17.0 \mathrm{~m}, 28.10 .98$; WAM C 29456 (2 females), DA2/99/04, 4 n. mls NNW of Cohen I. $\left(20^{\circ} 19.64 \mathrm{~S}, 116^{\circ} 45.75^{\prime} \mathrm{E}\right.$ to $\left.20^{\circ} 19.82^{\prime} \mathrm{S}, 116^{\circ} 45.98^{\prime} \mathrm{E}\right)$, rake box dredge, 42.0-43.0 m, 14.07.99; WAM C 29531 (1 female ovig.), DA2/99/ $05,4 \mathrm{n}$. mls NNW of Cohen I. $\left(20^{\circ} 19.64^{\prime} \mathrm{S}, 116^{\circ} 45.75 \mathrm{E}\right.$ to $\left.20^{\circ} 19.82^{\prime} \mathrm{S}, 116^{\circ} 45.98^{\prime} \mathrm{E}\right)$, rake box dredge, 14.07 .99 ; WAM C 29482 (1 female ovig.), DA2/99/06, $2.7 \mathrm{n}$. $\mathrm{mls}$ ESE of $\mathrm{C}$. Legendre $\left(20^{\circ} 21.69^{\prime} \mathrm{S}, 116^{\circ} 52.40^{\prime} \mathrm{E}\right.$ to $20^{\circ} 21.23^{\prime} \mathrm{S}, 116^{\circ} 52.36^{\prime} \mathrm{E}$ ), rake box dredge, 33.0-36.0 m, 14.07.99; WAM C 29487 (1 indet.), DA2/99/08; $3.6 \mathrm{n} \mathrm{m} / \mathrm{s}$ NNE of NW point of Delambre I $\left(20^{\circ} 22.76^{\prime} \mathrm{S}, 117^{\circ} 02.23^{\prime} \mathrm{E}\right.$ to $\left.20^{\circ} 23.12^{\prime} \mathrm{S}, 117^{\circ} 02.14^{\prime} \mathrm{E}\right)$, rake box dredge, $30.0-31.0 \mathrm{~m}, 15.07 .99$; WAM C 29545 (1 female ovig.), DA2/99/09, $-5.5 \mathrm{n} \mathrm{mls} \mathrm{N}$ of $\mathrm{NE}$ comer of Delambre I. $\left(20^{\circ} 20.38^{\prime} \mathrm{S}, 117^{\circ} 05.22^{\prime} \mathrm{E}\right.$ to $20^{\circ} 20.68^{\prime} \mathrm{S}, 117^{\circ} 05.63^{\prime} \mathrm{E}$ ), rake box dredge, $31.0-34.5$ m, 15.07.99; WAM C 33624 (1 female ovig.), DA2/99/ $13 ; \sim 2.25 \mathrm{n} \mathrm{mls}$ off Haüy I $\left(20^{\circ} 26.52 \mathrm{~S}, 117^{\circ} 00.50^{\prime} \mathrm{E}\right.$ to $20^{\circ} 26.27^{\prime} \mathrm{S}, 117^{\circ} 00.56^{\prime} \mathrm{E}$ ), rake box dredge, $19.5 . \mathrm{m}$, 16.07.99; WAM C 29508 (1 male, 1 female), DA2/99/ $22, \sim 7.1 \mathrm{n} . \mathrm{mls}$ WNW of C. Legendre $\left(20^{\circ} 19.43^{\prime} \mathrm{S}\right.$, $116^{\circ} 42.61^{\prime} \mathrm{E}$ to $\left.20^{\circ} 19.69^{\prime} \mathrm{S}, 116^{\circ} 42.22^{\prime} \mathrm{E}\right)$, rake box dredge, 37.0-38.0 m, 17.07.99; WAM C 29546 (1 indet.), DA2/99/32, $4.8 \mathrm{n}$. mls NE of Courtenay Head Light, Malus I. $\left(20^{\circ} 26.95^{\prime} \mathrm{S}, 116^{\circ} 44.86^{\prime} \mathrm{E}\right.$ to $20^{\circ} 27.39 \mathrm{~S}, 116^{\circ} 44.28^{\prime} \mathrm{E}$ ), rake box dredge, 15.0-16.0 m, 18.07.99; WAM C 33625 (1 female, 3 females ovig. 1 indet.), DA2/99/37, $2.5 \mathrm{n} \mathrm{mls} \mathrm{WNW} \mathrm{of} \mathrm{Marks} \mathrm{Pt,}$ West Lewis I. $\left(20^{\circ} 36.54 ' \mathrm{~S}, 116^{\circ} 34.98^{\prime} \mathrm{E}\right.$ to $20^{\circ} 36.11^{\prime} \mathrm{S}$, $\left.116^{\circ} 35.02^{\prime} \mathrm{E}\right)$, rake box dredge, 14.0-15.0 m, 19.07.99; WAM C 29525 ( 2 indet.), DA2/99/39, 1 n. mile ENE of Bluff Pt, Enderby 1. $\left(20^{\circ} 37.05^{\prime} \mathrm{S}, 116^{\circ} 33.86^{\prime} \mathrm{E}\right.$ to $20^{\circ} 37.56^{\prime} \mathrm{S}, 116^{\circ} 33.45^{\prime} \mathrm{E}$ ), rake box dredge, $13.0-14.0$ m, 19.07.99; WAM C 33626 (1 female ovig., 1 indet.), DA2/99/49, $3.3 \mathrm{n}$. mls just $S$ of $W$ of $W$ point of Eaglehawk I. $\left(20^{\circ} 40.30^{\prime} \mathrm{S}, 116^{\circ} 22.59^{\prime} \mathrm{E}\right.$ to $20^{\circ} 39^{\prime} 81^{\prime} \mathrm{S}$, $116^{\circ} 22.60^{\prime} \mathrm{E}$ ), rake box dredge, $15.5-16.0 \mathrm{~m}, 20.07 .99$ WAM C 29470 (1 female ovig., 1 indet.), DA2/99/60, - 2.9 n. mls ESE of Courtenay Head Light, Malus I. (20 $31.38^{\prime} \mathrm{S}, 116^{\circ} 44.24^{\prime} \mathrm{E}$ to $\left.20^{\circ} 31.72^{\prime} \mathrm{S}, 116^{\circ} 43.80^{\prime} \mathrm{E}\right)$, rake box dredge, $16.0-17.0 \mathrm{~m}, 22.07 .99$; WAM C 29467 ( 1 indet.), DA2/99/63, 1.1 n. mls NNE of light on East Intercourse I. $\left(20^{\circ} 38.35^{\prime} \mathrm{S}, 116^{\circ} 41.23^{\prime} \mathrm{E}\right.$ to $20^{\circ} 38.23^{\prime} \mathrm{S}, 116^{\circ} 41.44^{\prime} \mathrm{E}$ ), rake box dredge, 11.5-12.0 m, 23.07.99; WAM C 29472 (1 female ovig.), DA2/99/ $63, \sim 1.1 \mathrm{n} . \mathrm{mls}$ NNE of light on East Intercourse I. $\left(20^{\circ} 38.35^{\prime} \mathrm{S}, 116^{\circ} 41.23^{\prime} \mathrm{E}\right.$ to $\left.20^{\circ} 38.23^{\prime} \mathrm{S}, 116^{\circ} 41.44^{\prime} \mathrm{E}\right)$, rake box dredge, $11.5-12.0 \mathrm{~m}, 23.07 .99$; WAM C 29495 (1 female), DA2/99/63, $1.1 \mathrm{n}$. mls NNE of light on East Intercourse I. $\left(20^{\circ} 38.35^{\prime} \mathrm{S}, 116^{\circ} 41.23^{\prime} \mathrm{E}\right.$ to $\left.20^{\circ} 38.23^{\prime} \mathrm{S}, 116^{\circ} 41.44^{\prime} \mathrm{E}\right)$, rake box dredge, 11.5-12.0 m, 23.07.99; WAM C 29505 (1 female ovig.), DA2/99/ $63,-1.1 \mathrm{n}$. mls NNE of light on East Intercourse $\mathrm{I}$. $\left(20^{\circ} 38.35^{\prime} \mathrm{S}, 116^{\circ} 41.23^{\prime} \mathrm{E}\right.$ to $\left.20^{\circ} 38.23^{\prime} \mathrm{S}, 116^{\circ} 41.44^{\prime} \mathrm{E}\right)$, rake box dredge, $11.5-12.0 \mathrm{~m}, 23.07 .99$; WAM C 33627 (1 female ovig,), DA2/99/65, 2.4 n. mls NW of light on East Intercourse I. (2038.31'S, $116^{\circ} 38.46^{\prime} \mathrm{E}$ to $20^{\circ} 38.77^{\prime} \mathrm{S}, 116^{\circ} 38.54^{\prime} \mathrm{E}$ ), rake box dredge, 10.0-15.0 m, 23.07.99; WAM C 29481 (1 female, 1 female ovig.), DA2/99/71, 4.6 n. mls $S$ of Rocky Head, Enderby I. $(-4.6 \mathrm{n} . \mathrm{mls} S$ of Rocky Head, Enderby I. $(-4.6 \mathrm{n}$. mls S of Rocky Head, Enderby 1.), rake box dredge, 10.5 m, 24.07.99; WAM C 29483 (2 females ovig.), DA2/ 9972, $-5.5 \mathrm{n} \mathrm{mls}$ SSW of Rocky Head, Enderby I. $\left(20^{\circ} 42.13^{\prime} \mathrm{S}, 116^{\circ} 26.22^{\prime} \mathrm{E}\right.$ to $\left.20^{\circ} 42.12^{\prime} \mathrm{S}, 116^{\circ} 26.52^{\prime} \mathrm{E}\right)$, rake box dredge, $10.0 \mathrm{~m}, 24.07 .99$; WAM C 29447 (1 male, 2 females ovig., 2 indet.), DA2/99/73, 24.07.99; $3.25 \mathrm{n} \mathrm{mls} S$ of Rocky Head, Enderby I. (20 40.14'S, $116^{\circ} 27.69^{\prime} \mathrm{E}$ to $\left.20^{\circ} 39.93^{\prime} \mathrm{S}, 116^{\circ} 27.96^{\prime} \mathrm{E}\right)$, rake box dredge, $12.5 \mathrm{~m}, 24.07 .99$; WAM C 33628 (2 indet.), DA2/99/73, 24.07.99; $3.25 \mathrm{n} \mathrm{mls} \mathrm{S}$ of Rocky Head, Enderby I. $\left(20^{\circ} 40.14^{\prime} \mathrm{S}, 116^{\circ} 27.69^{\prime} \mathrm{E}\right.$ to $20^{\circ} 39.93^{\prime} \mathrm{S}$, $116^{\circ} 27.96^{\prime} \mathrm{E}$ ), rake box dredge, $12.5 \mathrm{~m}, 24.07 .99$; WAM C 33629 (1 indet.), DA2/99/75, - $0.75 \mathrm{n}$. mls E of NE point of Goodwyn I. (2032.16's, 11633.70'E to $20^{\circ} 31.70^{\prime} \mathrm{S}, 116^{\circ} 33.20^{\prime} \mathrm{E}$ ), rake box dredge, $14.0-19.0$ m, 25.07.99; WAM C 33358 (1 indet.), DA2/99/83, $3.15 \mathrm{n} \mathrm{m} / \mathrm{s}$ ENE of NE point of Goodwyn I. $\left(20^{\circ} 31.60^{\prime} \mathrm{S}, 116^{\circ} 36.19^{\prime} \mathrm{E}\right.$ to $\left.20^{\circ} 31.37^{\prime} \mathrm{S}, 116^{\circ} 35.76^{\prime} \mathrm{E}\right)$, 11.5-11.7 m, 26.07.99; WAM C 33630 (2 indet.), DA2) 99/91, 1.4 n. mls ESE of Tish Pt, Rosemary I. $\left(20^{\circ} 30.48^{\prime} \mathrm{S}, 116^{\circ} 36.53^{\prime} \mathrm{E}\right.$ to $\left.20^{\circ} 30.27^{\prime} \mathrm{S}, 116^{\circ} 36.86^{\prime} \mathrm{E}\right)$, 9.0-10.0 m, 26.07.99; WAM C 33785 (1 indet.), DA2/ 99/91, $1.4 \mathrm{n}$. mls ESE of Tish Pt, Rosemary I. $\left(20^{\circ} 30.48^{\prime} \mathrm{S}, 116^{\circ} 36.53^{\prime} \mathrm{E}\right.$ to $\left.20^{\circ} 30.27^{\prime} \mathrm{S}, 116^{\circ} 36.86^{\prime} \mathrm{E}\right)$, 9.0-10.0 m, 26.07.99; WAM C 33631 (1 female, 1 indet.), DA2/99/95, $1.1 \mathrm{n} . \mathrm{mls} W$ of Bluff $\mathrm{Pt}$ $\left(20^{\circ} 37.37^{\prime} \mathrm{S}, 116^{\circ} 31.69^{\prime} \mathrm{E}\right.$ to $\left.20^{\circ} 37.45^{\prime} \mathrm{S}, 116^{\circ} 31.58^{\prime} \mathrm{E}\right)$, 5.0-7.0 m, 27.07.99; WAM C 29514 (1 female, 1 female ovig., 1 indet.), DA2/99/99, $1.5 \mathrm{n}$. mls $\mathrm{W}$ of Rocky Head, Enderby I. (20 36.98'S, 116 26.25'E to $\left.20^{\circ} 36.99^{\prime} \mathrm{S}, 116^{\circ} 26.36^{\prime} \mathrm{E}\right), 18.0-19.0 \mathrm{~m}, 28.07 .99$; WAM C 33632 (1 female ovig., 2 indet.), DA3/99/37, Malus Is $\left(20^{\circ} 30.632^{\prime} \mathrm{S}, 116^{\circ} 38.788^{\prime} \mathrm{E}\right), 2.0-3.5 \mathrm{~m}, 27.08 .99$ WAM C 27735 (2 females ovig.), DA3/99/39, Brigadier I. $\left(20^{\circ} 25.411\right.$ 'S, $\left.116^{\circ} 37.578^{\prime} \mathrm{E}\right), 15.0-27.0 \mathrm{~m}$, 28.08.99; WAM C 33787 (1 indet.), DA3/99/41, Georgeff Reefs $\left(20^{\circ} 29.339^{\prime} \mathrm{S}, 116^{\circ} 36.798^{\prime} \mathrm{E}\right), 1.0-4.0 \mathrm{~m}$, 28-29.08.99; WAM C 27748 (1 female ovig., 1 indet.) DA3/99/47, Kendrew I. (20²9.671'S, $\left.116^{\circ} 32.519^{\prime} \mathrm{E}\right)$, 4.0-5.0 m, 30.08.99; WAM C 33788 (1 indet.), DA3/ 99/47, Kendrew I. (2029.671'S, $\left.116^{\circ} 32.519^{\prime} \mathrm{E}\right), 4.0-5.0$ m, 30.08.99; WAM C 27758 (1 female ovig., 1 indet.), DA3/99/56, Eaglehawk I. (2038.985'S, 116 26.210'E), 2.0-11.0 m, 03/09/99; WAM C 28078 (1 indet., 1 indet.), DA3/99/56, Eaglehawk I. (20 38.985's, $\left.116^{\circ} 26.210^{\prime} \mathrm{E}\right), 2.0-11.0 \mathrm{~m}, 03 / 09 / 99$; WAM C $27758(2$ females ovig., 5 indet.), DA3/99/65, Enderby I. $\left(20^{\circ} 37.111 \mathrm{~S}, 116^{\circ} 26.780^{\prime} \mathrm{E}\right), 13.0-15.0 \mathrm{~m}, 06.09 .99$ WAM C 27769 (1 male, 1 female ovig.), DA3/99/65, Enderby 1. (20 37.111'S, 116 26.780' E), 13.0-15.0 m, 06.09.99; WAM C 27772 (1 female), DA3/99/67 
Nelson Rocks (2026.511's, $\left.116^{\circ} 40.256^{\prime} \mathrm{E}\right), 6.0-24.0 \mathrm{~m}$ 07.09.99; WAM C 33633 (1 female ovig.). DA3/99/68, Nelson Rocks (2027.998'S, $\left.116^{\circ} 39.707^{\prime} \mathrm{E}\right), 6.5 \mathrm{~m}$, 07.09.99.

\section{Previous reported range}

Suez Canal, the Red Sea, Persian Gulf, Sri Lanka, Maldive and Laccadive Archipelagoes, Singapore, Indonesia, Thailand, Shanghai, Japan, Sulu Sea; in Australia, from Western Australia across northern Australia and south to Bundaberg, Queensland, the Herald Group, and the Coral Sea (Banner and Banner, 1975).

\section{Depth range and habitat}

Shallow water to $125 \mathrm{~m}$, amongst alcyonarians and sponges, in dead coral heads, amongst shells, and associated with a bryozoan (Banner and Banner, 1975; Chace, 1988). The specimens from the Dampier Archipelago were taken from the lower intertidal zone to a depth of $43 \mathrm{~m}$ amongst rocks, sand, mud, rubble, corals, gorgonians and soft corals. A specimen from station DA1/15 was collected from an unidentified alcyonacean.

\section{Colour in life}

White, with four small simple red chromatophores in approximate line between eyes (Yaldwyn, in Banner and Banner, 1975). See photos in Minemizu (200: 75) and Kato and Okuno (2001: 50).

\section{Synalpheus neptunus neptunus (Dana, 1852)}

\section{Material examined}

Western Australia, Dampier Archipelago. WAM C 33789 (1 female), DA1/98/07, Gidley I. (2028.010'S, $\left.116^{\circ} 47.720^{\prime} \mathrm{E}\right), 0.0-2.0 \mathrm{~m}, 19.10 .98$; WAM C 29518 (1 female), DA2/99/10, $1.9 \mathrm{n} \mathrm{mls} \mathrm{N}$ of NE point of Delambre I. $\left(20^{\circ} 23.97^{\prime} \mathrm{S}, 117^{\circ} 04.82^{\prime} \mathrm{E}\right.$ to $20^{\circ} 23.72^{\prime} \mathrm{S}, 117^{\circ} 04.70^{\prime} \mathrm{E}$ ), rake box dredge, $29.0 \mathrm{~m}$, 15.07.99; WAM C 29506 (1 indet.), DA2/99/33, 3.3 n $\mathrm{mls}$ NNE of Courtenay Head Light, Malus $I$. $\left(20^{\circ} 27.41^{\prime} \mathrm{S}, 116^{\circ} 42.57^{\prime} \mathrm{E}\right.$ to $\left.20^{\circ} 27.33^{\prime} \mathrm{S}, 116^{\circ} 43.05^{\prime} \mathrm{E}\right)$, rake box dredge, $18.0-21.0 \mathrm{~m}, 18.07 .99$; WAM C 29551 (1 female, 1 indet.), DA2/99/50, 6.5 n. mls $W$ of Rocky Head, Enderby I (20 $37.10^{\prime} S, 116^{\circ} 20.9^{\prime} \mathrm{E}$ to $20^{\circ} 37.28^{\prime} \mathrm{S}, 116^{\circ} 21.08^{\prime} \mathrm{E}$ ), rake box dredge, 24.0 $25.0 \mathrm{~m}, 20.07 .99$; WAM C 29484 (2 females ovig.), DA2/99/68; $3.6 \mathrm{n}$. mls $\mathrm{S}$ of Bluff Pt., Enderby I. $\left(20^{\circ} 40.93^{\prime} \mathrm{S}, 116^{\circ} 33.21^{\prime} \mathrm{E}\right.$ to $\left.20^{\circ} 40.63^{\prime} \mathrm{S}, 116^{\circ} 33.36^{\prime} \mathrm{E}\right)$, rake box dredge, 9.0-9.2 $\mathrm{m}, 23.07 .88$; WAM C 33790 (1 female ovig.), DA2/99/85, $2.6 \mathrm{n}$. mls E of E point of Brigadier I. $\left(20^{\circ} 26.38^{\prime} \mathrm{S}, 116^{\circ} 39.76^{\prime} \mathrm{E}\right.$ to $20^{\circ} 26.09^{\prime} \mathrm{S}$, $116^{\circ} 40.10^{\prime} \mathrm{E}$ ), rake box dredge, $28.0-29.0 \mathrm{~m}$, 26.07.99; WAM C 27760 (1 female, 1 female ovig.), DA3/99/56, Eaglehawk I. $\left(20^{\circ} 38.985^{\prime} S, 116^{\circ} 26.210^{\prime} \mathrm{E}\right)$, 2.0-11.0,03/09/99.

\section{Previous reported range}

The Red Sea, Indian Ocean, Indonesia, China, Japan, Sulu Sea; in Australia, from western Australia across northern Australia to Port Jackson, New South Wales (Banner and Banner, 1975).

\section{Depth range and habitat}

Shallow water to $70 \mathrm{~m}$, amongst sponges and coral heads (Banner and Banner, 1975; Chace, 1988). The specimens from the Dampier Archipelago came from the lowest intertidal zone to a depth of $29 \mathrm{~m}$, amongst corals, sponges, sand, rocks and other mixed habitat.

\section{Colour in life}

Not reported.

\section{Additional notes}

Chace (1988) preferred not to use subspecific designations in this variable species, noting that two specimens from the same collecting locality but of different total lengths displayed features typical of two subspecies. All of the specimens from the Dampier Archipelago agree with the description of the typical subspecies.

\section{Synalpheus paraneomeris Coutière, 1905}

\section{Material examined}

Western Australia, Dampier Archipelago. WAM C 33791 (1 female), DA3/99/61, West Lewis I. (2034.693', 116 $\left.39.698^{\circ}\right), 3.0-5.0 \mathrm{~m}, 04.09 .99$.

\section{Previous reported range}

Maldive Archipelago, Indonesia, Japan, Philippines, Mariana, Caroline, Marshall, and Gilbert Is; Samoa, Line and Hawaiian Islands; in Australia northeastern, from the Great Barrier Reef to off Cape Moreton, near Brisbane, Queensland (Banner, and Banner, 1975). This is the first record of the species in northwestern Australia.

\section{Depth range and habitat}

Dead coral heads, intertidal to $126 \mathrm{~m}$ (Banner and Banner, 1975; Chace, 1988). The specimen from West Lewis Island was taken at a depth of 3-5 m amongst sand, rubble and small colonies of corals.

\section{Colour in life}

Olive brown to gray, reddish; greenish with scattering of small red chromatophores (Yaldwyn, in Banner and Banner, 1975).

\section{Synalpheus pococki Coutière, 1898}

\section{Material examined}

Western Australia, Dampier Archipelago. WAM 
C 33792 (1 female ovig. I indet.), DA2/99/99, - 1.5 n. $\mathrm{mls} \mathrm{W}$ of Rocky Head, Enderby 1. (2036.98's, $11626.25^{\circ} \mathrm{E}$ to $\left.20^{\circ} 36.99^{\circ} \mathrm{S}, 11626.36^{\circ} \mathrm{E}\right), 18.0-19.0 \mathrm{~m}$, 28.07 .99 .

\section{Previous reported range}

Aru Island, Indonesia; in Australia, from the Arafura Sea, Darwin (Northern Territory), and Torres Straits (Banner and Banner, 1975).

\section{Depth range and habitat}

From depths of 13-18 m, collected from growth on a pearl shell (Banner and Banner, 1975). The specimen from the Dampier Archipelago was taken at a depth of $17-19 \mathrm{~m}$, amongst rocks, sponges, corals, gorgonians and hydroids.

\section{Colour in life}

Not reported.

\section{Additional notes}

Banner and Banner (1975) suggested that the peculiar shape of the propodi of the third to fifth pereopods might be an adaptation for a special environment, but did not know what this habitat might be. Unfortunately, the specimen from station DA2/99 was dredged, so it could not be associated with any particular host species.

\section{Synalpheus quadriarticulatus Banner and Banner, 1975}

\section{Material examined}

Western Australia, Dampier Archipelago. WAM C 25691 (1 temale), DA1/98/31, Searipple Passage (20 31.230'S, 116 51.182'E), intertidal, 28.10.98; WAM C 25841 ( 9 indet.), DA1/98/31, Searipple Passage (2031.230'S, $\left.116^{\circ} 51.182^{\prime} \mathrm{E}\right)$, intertidal, 28.10.98; WAM C 25838 (1 female, 1 indet.), DA1/98/33; Angel I. (20²7.965'S, $\left.116^{\circ} 49.692^{\prime} \mathrm{E}\right), 1.0-8.0 \mathrm{~m}, 29.10 .98$; WAM C 29541 (1 indet.) DA2/99/09, $5.5 \mathrm{n} \mathrm{mls} \mathrm{N}$ of $\mathrm{NE}$ corner of Delambre I. $\left(20^{\circ} 20.38^{\prime} \mathrm{S}, 117^{\circ} 05.22^{\prime} \mathrm{E}\right.$ to $20^{\circ} 20.68^{\prime} \mathrm{S}, 117^{\circ} 05.63^{\prime} \mathrm{E}$ ), rake box dredge, 31.0-34.5 m, 15.07.99; WAM C 33634 (14 indet.), DA2/99/50, $6.5 \mathrm{n} . \mathrm{mls}$ W of Rocky Head, Enderby I. (2037.10's, $116^{\circ} 20.99^{\prime} \mathrm{E}$ to $20^{\circ} 37.28^{\prime} \mathrm{S}, 116^{\circ} 21.08^{\prime} \mathrm{E}$ ), rake box dredge, 24.0-25.0m, 20.07.99; WAM C 29519 (2 females, 11 indet.), DA2/99/65, 2.4 n. mls NW of light on East Intercourse I. $\left(20^{\circ} 38.31^{\prime} \mathrm{S}, 116^{\circ} 38.46^{\prime} \mathrm{E}\right.$ to $\left.20^{\circ} 38.77^{\prime} \mathrm{S}, 116^{\circ} 38.54^{\prime} \mathrm{E}\right)$, rake box dredge, 10.0-15.0 m, 23.07.99; WAM C 29475 (2 indet), DA2/99/65, $2.4 \mathrm{n} . \mathrm{m} / \mathrm{s}$ NW of light on East Intercourse 1. $\left(20^{\circ} 38.31^{\prime} \mathrm{S}, 116^{\circ} 38.46^{\circ} \mathrm{E}\right.$ to $\left.20^{\circ} 38.77^{\prime} \mathrm{S}, 116^{\circ} 38.54^{\prime} \mathrm{E}\right)$, rake box dredge, $10.0-15.0 \mathrm{~m}, 23.07 .99$; WAM C 29504 ( 2 females, 2 indet.), DA2/99/84, $2.9 \mathrm{n} \mathrm{mls} \mathrm{E}$ of Tish Pt, Rosemary 1. $\left(20^{\circ} 29.94^{\prime} \mathrm{S}, 116^{\circ} 38.11^{\prime} \mathrm{E}\right.$ to $\left.20^{\circ} 29.84^{\prime} \mathrm{S}, 116^{\circ} 38.64^{\prime} \mathrm{E}\right)$, rake box dredge, 12.5-15.0 m, 26.07.99; WAM C 33635 (1 temale ovig., 4 indet.),
D) A2/99/84, $2.9 \mathrm{n} \mathrm{mls} \mathrm{E} \mathrm{of} \mathrm{lish} \mathrm{Pt,} \mathrm{Rosemary} \mathrm{I.}$ (2029.94'S, 116 38.11'E to 2029.84'S, $11638.64 \mathrm{~F}$ ), rake box dredge, 12.5-15.0 m, 26.07.99; WAM C 29461 (3 females, 7 indet.), DA2/99/98, - $2.55 \mathrm{n} . \mathrm{mls}$ SSW of Bluff P't, Enderby I. (2039.81'S, 11631.92' E to $20^{\circ} 39.34 \mathrm{~S}, 116^{\circ} 32.12^{\prime} \mathrm{E}$ ), rake box dredge, $10.5-11.0$ m, 28.07.99; WAM C 29522 ( 1 female), DA2/99/98, $2.55 \mathrm{n} . \mathrm{mls}$ SSW of Bluff P't, Enderby I. $\left(20^{\circ} 39.81^{\prime} \mathrm{S}\right.$, $116^{\circ} 31.92^{\prime} \mathrm{E}$ to $20^{\circ} 39.34^{\prime} \mathrm{S}, 116^{\prime} 32.12^{\prime} \mathrm{E}$ ), rake box dredge, 10.5-11.0 m, 28.07.99; WAM C 27754 (2 indet.), DA2/99/52, $10 \mathrm{n} . \mathrm{mls} W$ of SW point of Goodwyn I. $\left(20^{\circ} 31.85^{\prime}\right.$ S, $11621.48^{\prime} \mathrm{E}$ to $20^{\circ} 31.97^{\prime} \mathrm{S}$, $116^{\circ} 21.99^{\circ} \mathrm{E}$ ), rake box dredge, $31.2-32.3 \mathrm{~m}, 21.07 .99$.

\section{Previous reported range}

Philippines; castern Australia, from Torres Staits, north Queensland (Banner and Banner, 1975; Chace, 1988). This is the first record of the species from northwestern Australia.

\section{Depth range and habitat}

3-18 $\mathrm{m}$, in sponges amongst dead coral heads. The specimens from the Dampier Archipelago were taken at depths of 9-26 m, amongst sponges.

\section{Colour in life}

Not reported. One specimen from DA2/98 had a dark purple colour.

\section{Additional notes}

Banner and Banner (1975) noted variation in the length of the rostrum relative to the orbital teeth, size and shape of the antennules, length of the stylocerite, spine of the scaphocerite, and size and shape of both chelae. Amongst the specimens from DA2/84, the rostrum is the same length as the orbital teeth, but in one specimen, all of these frontal projections are weakly developed. In one specimen from DA2/84 and the specimen from DA2/09, the rostrum is absent. In the same specimen from DA2/84, only the right orbital tooth is developed; in another from the same station, the rostrum is represented by a small knob.

In the material from given stations, we consistently found small specimens of indeterminate sex associated with much larger females. It would be worthwhile to look for this species in situ amongst the sponges in which it lives. The habitat and size range suggests that this might be a eusocial species, in which a large female lives in association with a few males and a group of non-reproducing workers. See Duffy (1996) for more information on eusocial species of Symalpheus.

\section{Synalpheus stimpsoni (De Man, 1888)}

\section{Material examined}

Western Australia, Dampier Archipelago. WAM 
C 25681 (1 female, 1 female ovig.), DA1/98/33; Angel I. (202 $\left.27.965^{\prime} \mathrm{S}, 116^{\circ} 49.692^{\prime} \mathrm{E}\right), 1.0-8.0 \mathrm{~m}$, 29.10.98; WAM C 33643 (1 female ovig.), DA2/99/ $05,4 \mathrm{n}$. mls NNW of Cohen I. $\left(20^{\circ} 19.64^{\prime} \mathrm{S}\right.$, $116^{\circ} 45.75^{\prime} \mathrm{E}$ to $\left.20^{\circ} 19.82^{\prime} \mathrm{S}, 116^{\circ} 45.98^{\prime} \mathrm{E}\right)$, rake box dredge, 14.07.99; WAM C 33644 (1 female), DA2/ $99 / 09, \sim 5.5 \mathrm{n} \mathrm{mls} \mathrm{N}$ of NE corner of Delambre $\mathrm{I}$. $\left(20^{\circ} 20.38^{\prime} \mathrm{S}, 117^{\circ} 05.22^{\prime} \mathrm{E}\right.$ to $\left.20^{\circ} 20.68^{\prime} \mathrm{S}, 117^{\circ} 05.63^{\prime} \mathrm{E}\right)$, rake box dredge, $31.0-34.5 \mathrm{~m}, 15.07 .99$; WAM C 33645 (1 female), DA2/99/13; $2.25 \mathrm{n}$ mls off Haüy I $\left(20^{\circ} 26.52^{\prime} \mathrm{S}, 117^{\circ} 00.50^{\prime} \mathrm{E}\right.$ to $\left.20^{\circ} 26.27^{\prime} \mathrm{S}, 117^{\circ} 00.56^{\prime} \mathrm{E}\right)$, rake box dredge, 19.5. $\mathrm{m}, 16.07 .99 ;$ WAM C 29511 (2 females), DA2/99/23, $8.9 \mathrm{n}$. mls $W$ of Cape Legendre $\left(20^{\circ} 21.00^{\prime} \mathrm{S}, 116^{\circ} 40.39^{\prime} \mathrm{E}\right.$; to $20^{\circ} 21.35^{\prime} \mathrm{S}$, $\left.116^{\circ} 40.19^{\prime} \mathrm{E}\right)$, rake box dredge, $37.0 \mathrm{~m}, 17.07 .99$; WAM C 33646 (1 male), DA2/99/24, 5.5 n. mls N of Lady Nora I $\left(20^{\circ} 21.79^{\prime} \mathrm{S}, 116^{\circ} 38.05^{\prime} \mathrm{E}\right.$ to $20^{\circ} 22.00^{\prime} \mathrm{S}$, $\left.116^{\circ} 37.81^{\prime} \mathrm{E}\right)$, rake box dredge, $38.5 \mathrm{~m}, 17.07 .99$; WAM C 29516 (5 females), DA2/99/25, $~ 5.2 \mathrm{n}$. mls $\mathrm{N}$ of Rosemary I. $\left(20^{\circ} 22.29^{\prime} \mathrm{S}, 116^{\circ} 35.56^{\prime} \mathrm{E}\right.$ to $\left.20^{\circ} 22.62^{\prime} \mathrm{S}, 116^{\circ} 35.44^{\prime} \mathrm{E}\right)$, rake box dredge, $39.0 \mathrm{~m}$, 17.07.99; WAM C 33647 (1 female), DA2/99/33; 3.3 n mls NNE of Courtenay Head Light, Malus I. $\left(20^{\circ} 27.41 ' \mathrm{~S}, 116^{\circ} 42.57^{\prime} \mathrm{E}\right.$ to $\left.20^{\circ} 27.33^{\prime} \mathrm{S}, 116^{\circ} 43.05^{\prime} \mathrm{E}\right)$, rake box dredge, $18.0-21.0 \mathrm{~m}, 18.07 .99$; WAM C 29486 (3 males, 1 female ovig.), DA2/99/41, $1.3 \mathrm{n}$. mls $\mathrm{N}$ of Rocky Head, Enderby I. $\left(20^{\circ} 35.63 \mathrm{~S}\right.$, $116^{\circ} 28.07^{\prime} \mathrm{E}$ to $\left.20^{\circ} 35.09^{\prime} \mathrm{S}, 116^{\circ} 27.81^{\prime} \mathrm{E}\right)$, rake box dredge, 16.0-17.4 m, 20.07.99; WAM C 29491 (1 female), DA2/99/43, $2.9 \mathrm{n}$. mls WNW of SW point of Goodwyn I. (20³1.60'S, $116^{\circ} 29.03^{\prime} \mathrm{E}$ to $20^{\circ} 32.02^{\prime} \mathrm{S}$, $116^{\circ} 29.18^{\prime} \mathrm{E}$ ), rake box dredge, $21.0-22.0 \mathrm{~m}, 20.07 .99$; WAM C 33793 (1 female), DA2/99/50, 6.5 n. mls $W$ of Rocky Head, Enderby I (20 37.10'S, $116^{\circ} 20.99^{\prime} \mathrm{E}$ to $20^{\circ} 37.28^{\prime} \mathrm{S}, 116^{\circ} 21.08^{\prime} \mathrm{E}$ ), rake box dredge, 24.0-25.0 m, 20.07.99; WAM C 33648 (2 females ovig., 1 indet.), DA2/99/58; $1 \mathrm{n}$. mile NNE of Roly Rock, $20^{\circ} 29.11 \mathrm{~S}, 116^{\circ} 30.78^{\prime} \mathrm{E}$ to $20^{\circ} 29.35^{\prime} \mathrm{S}$, $\left.116^{\circ} 30.55^{\prime} \mathrm{E}\right)$, rake box dredge, $25.0-25.5 \mathrm{~m}, 21.07 .99$; WAM C 33794 (1 female ovig., 1 indet.), DA2/99/58; 1 n. mile NNE of Roly Rock, 20 29.11'S, $116^{\circ} 30.78^{\prime} \mathrm{E}$ to $\left.20^{\circ} 29.35^{\prime} \mathrm{S}, 116^{\circ} 30.55^{\prime} \mathrm{E}\right)$, rake box dredge, 25.0-25.5 m, 21.07.99; WAM C 27688 (1 female ovig.), DA2/99/62, Flying Foam Passage, DA2/99/62, $0.9 \mathrm{n}$. mls NE of $S$ point of Angel I. (20 $30.69^{\prime} \mathrm{S}, 116^{\circ} 48.58^{\prime} \mathrm{E}$ to $\left.20^{\circ} 31.17^{\prime} \mathrm{S}, 116^{\circ} 48.33^{\prime} \mathrm{E}\right)$, rake box dredge, 7.0-9.0 m, 22.07.99; WAM C 29458 (1 female, 1 indet.), DA2/99/78, $1.3 \mathrm{n}$. mls NE of NW Pt, Goodwyn I. $\left(20^{\circ} 31.09^{\prime} \mathrm{S}, 116^{\circ} 33.04^{\prime} \mathrm{E}\right.$ to $\left.20^{\circ} 31.17^{\prime} \mathrm{S}, 116^{\circ} 33.40^{\prime} \mathrm{E}\right), 14.0-15.0 \mathrm{~m}, 25.07 .99$; WAM C 29520 (1 indet.) DA2/99/77, $1.8 \mathrm{n} . \mathrm{mls}$ $\mathrm{NW}$ of NW point of Goodwyn I. $\left(20^{\circ} 30.57^{\prime} \mathrm{S}\right.$, $116^{\circ} 30.89^{\prime} \mathrm{E}$ to $\left.20^{\circ} 30.49^{\prime} \mathrm{S}, 116^{\circ} 30.91^{\prime} \mathrm{E}\right)$, rake box dredge, 13.0-14.0 m, 25.07.99; WAM C 27732 (1 male, 1 female ovig.), DA3/99/37, Malus Is (20³0.632'S, $\left.116^{\circ} 38.788^{\prime} \mathrm{E}\right), 2.0-3.5 \mathrm{~m}, 27.08 .99$; WAM C 27738 (1 indet.), DA3/99/41, Georgeff Reefs (20²9.339'S, 116 $\left.36.798^{\prime} \mathrm{E}\right), 1.0-4.0 \mathrm{~m}, 28-29.08 .99$; WAM C 27763 (1 female), DA2/99/61, 2.85 n. mls
NW of Phillip Pt, Burrup Peninsula $\left(20^{\circ} 35.33^{\prime} \mathrm{S}\right.$, $116^{\circ} 42.78^{\prime} \mathrm{E}$ to $20^{\circ} 34.83^{\prime} \mathrm{S}, 116^{\circ} 42.91^{\prime} \mathrm{E}$ ), rake box dredge, $11.0 \mathrm{~m}, 22.07 .99$; WAM C 27771 (1 female), DA3/99/67, Nelson Rocks (20²6.511'S, $\left.116^{\circ} 40.256^{\prime} \mathrm{E}\right), 6.0-24.0 \mathrm{~m}, 07.09 .99$.

\section{Previous reported range}

Eastern Africa, Madagascar, Indonesia, Singapore, Thailand, Celebes, Philippines, Japan, Marshal, Loyalty and Gilbert Islands; in Australia, from Western Australia across northern Australia to Sydney, New South Wales (Banner and Banner, 1975, Chace, 1988).

\section{Depth range and habitat}

Intertidal to $155 \mathrm{~m}$, frequently associated with crinoids, occasionally with alcyonarians and in dead corals heads and under rocks (Chace, 1988). The specimens from the Dampier Archipelago were taken from the lowest intertidal zone to a depth of $39 \mathrm{~m}$, on mixed bottoms or amongst crinoids.

\section{Colour in life}

Highly variable; matches the host. Pale green or white with longitudinal stripes (Banner and Banner, 1975), translucent with longitudinal red stripes, black with yellow stripes, dark red with yellow chromatophores (Debelius, 1999: 145; Minemizu, 200: 76), black (Gosliner et al., 1996).

\section{Additional notes}

Banner and Banner (1975) reported that this species often associates with the crinoids Comanthus purpurea and $C$. timorensis. Gosliner et al. (1996) reported the species from species of Comanthina and Oxycomanthus. The specimens from the Dampier Archipelago came from amongst Comanthus parvicirrus and Comanthus variabilis.

\section{Synalpheus streptodactylus Coutière, 1905}

\section{Material examined}

Western Australia, Dampier Archipelago. WAM C 25842 (1 female, 1 indet.), DA1/98/07, Gidley I. (20²8.010'S, $\left.116^{\circ} 47.720^{\prime} \mathrm{E}\right), 0.0-2.0 \mathrm{~m}, 19.10 .98$; WAM C 29544 (1 indet.), 4.8 n. mls NE of Courtenay Head Light, Malus I., $\left(20^{\circ} 26.95^{\prime} \mathrm{S}\right.$, $116^{\circ} 44.86^{\prime} \mathrm{E}$ to $20^{\circ} 27.39 \mathrm{~S}, 116^{\circ} 44.28^{\prime} \mathrm{E}$ ), rake box dredge, 15.0-16.0 m, 18.07.99; WAM C 33795 (1 indet.), DA2/99/38, $2.1 \mathrm{n}$. mls WSW of Marks Pt, West Lewis I. (20 $37.47^{\prime} \mathrm{S}, 116^{\circ} 35.37^{\prime} \mathrm{E}$ to $20^{\circ} 36.91^{\prime} \mathrm{S}$, $\left.116^{\circ} 35.33^{\prime} \mathrm{E}\right)$, rake box dredge, $11.0-13.0 \mathrm{~m}, 17.07 .99$; WAM C 29459 (1 female ovig.), DA2/99/49, $3.3 \mathrm{n}$. mls just $S$ of $W$ of $W$ point of Eaglehawk $I$. $\left(20^{\circ} 40.30^{\prime} \mathrm{S}, 116^{\circ} 22.59^{\prime} \mathrm{E}\right.$ to $\left.20^{\circ} 39^{\prime} 81^{\prime} \mathrm{S}, 116^{\circ} 22.60^{\prime} \mathrm{E}\right)$, rake box dredge, $15.5-16.0 \mathrm{~m}, 20.07 .99$; WAM C 33796 (2 indet.), DA2/99/68, -3.6 n. mls $S$ of Bluff Pt., Enderby I. $\left(20^{\circ} 40.93\right.$ 'S, $116^{\circ} 33.21^{\prime} \mathrm{E}$ to $20^{\circ} 40.63^{\prime} \mathrm{S}$, 
$\left.116^{\circ} 33.36^{\circ} \mathrm{E}\right)$, rake box dredge, 9.0-9.2 m, 23.07.88; WAM C 29496 (1 female, 1 indet.), DA2/99/71, 4.6 n. mls $\mathrm{S}$ of Rocky Head, Enderby I. (20 41.49'S, $116^{\circ} 28.05^{\prime} \mathrm{E}$ to $20^{\circ} 41.55^{\prime} \mathrm{S}, 116^{\circ} 28.36^{\prime} \mathrm{E}$ ), rake box dredge, $10.5 \mathrm{~m}, 24.07 .99$; WAM C 33797 (3 indet.), DA2/99/98, 2.55 n. mls SSW of Bluff Pt, Enderby I. $\left(20^{\circ} 39.81^{\prime} \mathrm{S}, 116^{\circ} 31.92^{\prime} \mathrm{E}\right.$ to $\left.20^{\circ} 39.34^{\prime} \mathrm{S}, 116^{\circ} 32.12^{\prime} \mathrm{E}\right)$, rake box dredge, $10.5-11.0 \mathrm{~m}, 28.07 .99$.

\section{Previous reported range}

The Red Sea, Ghardaqa, South Africa, Maldive and Laccadive Archipelagoes, Sumatra, Thailand, Philippines, Japan, Tonga, Samoa, Canton Islands, Hawaii; in Australia, on all coasts (Banner and Banner, 1975).

\section{Depth range and habitat}

Intertidal zone to $128 \mathrm{~m}$, often amongst sponges, amongst heads of dead coral, mud, sand, shell and driftwood (Banner and Banner, 1975; Chace, 1988). The specimens from the Dampier Archipelago came from the shore to a depth of $38.5 \mathrm{~m}$, amongst rocks, sand, mud, sponges, algae, and other mixed bottoms.

\section{Colour in life}

Salmon pink or brown, matching sponge host (Banner and Banner, 1975).

\section{Synalpheus theano De Man, 1910}

\section{Material examined}

Western Australia, Dampier Archipelago. WAM C 33798 (1 indet.), DA1/98/31, Searipple Passage $\left(20^{\circ} 31.230^{\prime} \mathrm{S}, 116^{\circ} 51.182^{\prime} \mathrm{E}\right)$, intertidal, 28.10.98.

\section{Previous reported range}

Philippines, Indonesia, Japan; in Australia, near Perth, Western Australia, across northern Australia to Port Jackson, New South Wales (Banner and Banner, 1975; Chace, 1988, Nomura and Asakura, 1998).

\section{Depth range and habitat}

Shallow water to $32 \mathrm{~m}$, in dead coral and sponges (Chace, 1988). The specimen from Searipple Passage was taken along shore amongst sponges, corals, reef and silt flats and oyster-covered boulders.

\section{Colour in life}

Not reported.

\section{Synalpheus tumidomanus? (Paulson, 1875)}

\section{Material examined}

Western Australia, Dampier Archipelago. WAM C 25865 (1 female ovig. [species identification uncertain]), DAl $/ 98 / 08$, Angel I. (20²9.180'S, $\left.116^{\circ} 47.711^{\prime} \mathrm{E}\right), 2.0-8.0 \mathrm{~m}, 20.10 .98$; WAM C 33799 (1 indet.), DA2/99/38, $2.1 \mathrm{n}$. mls WSW of Marks Pt, West Lewis I. $(\sim 2.1 \mathrm{n}$. mls WSW of Marks Pt, West Lewis I.), rake box dredge, 11.0-13.0 m, 17.07.99; WAM C 33800 (1 indet.), DA2/99/58, 1 n. mile NNE of Roly Rock (20'29.11'S, $116^{\circ} 30.78^{\prime} \mathrm{E}$ to $\left.20^{\circ} 29.35^{\prime} \mathrm{S}, 116^{\circ} 30.55^{\prime} \mathrm{E}\right)$, rake box dredge, 25.0-25.5 $\mathrm{m}, 21.07 .99$.

\section{Previous reported range}

Mediterranean coast of Israel, South Africa, the Red Sea, Persian Gulf, Sri Lanka, Maldive Archipelago, Singapore, Thailand, Indonesia, Philippines, Japan, Phoenix Archipelago; all shores of Australia; Norfolk I., Lord Howe I. (Banner and Banner, 1975).

\section{Depth range and habitat}

Intertidal zone to $148 \mathrm{~m}$, amongst dead coral and sponges. The specimens from the Dampier Archipelago were taken at depths of $2-16 \mathrm{~m}$, amongst rocks, sand, algae, corals and other invertebrates.

\section{Colour in life}

Not reported.

\section{Additional notes}

The specimen from DA1/08 is missing the minor chela, so the specific identity remains uncertain.

\section{DISCUSSION}

Of the 45 species of alpheids that could be identified with certainty, the majority have wide ranges over the Indian and Pacific Oceans. Eighteen species $(40 \%)$ range from the east coast of Africa or the Red Sea across the Indian Ocean to Australia, Japan, the Philippines and at least some of the islands of the central Pacific. Seventeen species (38\%) range from the east coast of Africa or the Red Sea to the western Pacific, from Japan to Australia and nearby islands. Six species (13\%) range from the eastern Indian Ocean to the western Pacific. Only four species (9\%) range completely across the Indo-Pacific to the islands or mainland of the eastern Pacific. There are no species thought to be endemic to northwestern Australia.

Alpheids are common inhabitants of rocky reefs, tidepools and coral reefs. Two species (Alpheus strenuus strenuus and $A$. inopinatus) were taken only in the intertidal zone, 11 were strictly subtidal and the other 32 ranged from the lower intertidal zone into the subtidal zone. Most of the species were taken in mixed habitats of rock, coral, sand, sponges, algae and other invertebrates. Alpheus rapacida was found in areas of sand and silt in 
intertidal and shallow subtidal areas; A. serenei was taken amongst sand, silt and rubble in subtidal areas. Synalpheus comatularum and S. stimpsoni associated with crinoids; Alpheus lottini was found amongst Pocillopora damicornis. Synalpheus neomeris was collected in association with an unidentified soft coral (Alcyonacea) and has been reported previously to associate with these colonies (Chace, 1988; Kato and Okuno, 2001). Synalpheus quadriarticulatus was reported to associate with sponges, but these were not identified.

As many as eight species of alpheids could be taken from a single station. Some of the species diversity is due to specializations for particular niches: for example, commensalism versus free living or digging galleries in rock versus living in sand under a rock. For the diverse members of the Alpheus edwardsi group, however, such specialization is not known. Cornfield and Alexander (1995) found that $A$. edwardsi and $A$. lobidens, morphologically similar and found in similar habitats, preferred slightly different substrates, related to the form of burrow they construct. Patton (1974) found that decapods inhabiting the coral Pocillopora damicornis preferred certain locations within the branches of the colony. It is likely that subtle specialization in location within a three-dimensional habitat and its neighboring sand or silt bottom enable multiple species of alpheids to cohabit in a very small area.

\section{REFERENCES}

Anker, A. (2003). New records of Salmoneus Holthuis, 1955 (Crustacea: Decapoda: Alpheidae) from northern Australia, with description of one new species and remarks on S. serratidigitus (Coutière, 1896). The Beagle 19: 101-117.

Banner, D.M. and Banner, A.H. (1973). The alpheid shrimp of Australia. Part 1: The lower genera. Records of the Australian Museum 28: 291-382.

Banner, D.M. and Banner, A.H. (1975). The alpheid shrimp of Australia. Part 2: The genus Synalpheus. Records of the Australian Museum 29: 267-389.

Banner, D.M. and Banner, A. H. (1982). The alpheid shrimp of Australia. Part 3: The remaining alpheids, principally the genus Alpheus and the family Ogyrididae. Records of the Australian Museum 34: $1-357$.

Chace, F.A. Jr. (1988). The caridean shrimps (Crustacea: Decapoda) of the Albatross Philippine Expedition, 1907-1910, Part 5: Family Alpheidae. Smithsonian Contributions to Zoology 466: 1-99.

Christoffersen, M. (1987). Phylogenetic relationships of hippolytid genera, with an assignment of new families for the Crangonoidea and Alpheoidea (Crustacea, Decapoda, Caridea). Cladistics 3: 348-362.

Confield, J.L. and Alexander, C.G. (1995). The distribution of two species of alpheid shrimp, Alpheus edwardsii and A. lobidens, on a tropical beach. Journal of the Marine Biological Association of the United Kingdom 75: 675-687.

Coutiere, H. (1899). Les "Alpheidae", morphologie externe et interne, formes larvaires, bionomie. Annales des Sciences Naturelles, Zoologie (8)9: 1-409.

Coutière, H. (1905). Les Alpheidae. In Stanley Gardiner, J., The Fauna and Geography of the Maldive and Laccadive Archipelagoes 2: 852-921.

Coutière, H. (1908). Sur quelques nouvelles espèces d'Alpheidae. Bulletin de la Société Philomathique de Paris 9: 191-216.

Coutiere, H. (1909). The American species of snapping shrimps of the genus Synalpheus. Proceedings of the United States National Museum 36: 1-93.

Davie, P.J.F. (2002). Crustacea: Malacostraca: Phyllocarida, Hoplocarida, Eucarida (Part 1), In Wells, A. and Houston, W.W.K. (eds), Zoological Catalogue of Australia 19.3A. Melbourne: CSIRO Publishing, Australia. pp xii +551 pp.

Debelius, H. (1999). Crustacea Guide of the world. IKANUnterwasserarchiv, Frankfurt. $321 \mathrm{pp}$.

Duffy, J.E. (1996). Eusociality in a coral-reef shrimp. Nature 381: 512-514.

Gosliner, T.M., Behrens, D.W. and Williams, G.C. (1996). Coral reef animals of the Indo-Pacific. Sea Challengers, Monterey, California. 314 pp.

Hayashi, K. and Nagata, M. 2002. Identity of Alpheus digitalis De Haan, 1844 and description of a new closely related species from the northwestern Pacific (Decapoda: Caridea: Alpheidae). Crustacean Research 31: 73-90.

Holthuis, L.B. (1993). The recent genera of the caridean and stenopodidean shrimps (Crustacea, Decapoda): with an appendix on the order Amphionidacea. National Naturhistorisch Museum, Leiden. $328 \mathrm{pp}$.

Hoover, J.P. (1998). Hawai'i's sea creatures. Mutual Publishing, Honolulu. $366 \mathrm{pp}$.

Hutchins, J.B. and Berry, P. (2004). Station map and list for the diving expeditions (DA1and DA3). In Jones, D.S. (ed.), Report on the results of the Western Australian Museum/Woodside Energy Ltd. Partnership to explore the marine biodiversity of the Dampier Archipelago, Western Australia 1998-2002. Records of the Western Australian Museum, Supplement 66: 7-14.

Hutchins, J.B. and Fromont, J. (2004). Station map and list for the workshop diving expedition (DA4). In Jones, D.S. (ed.), Report on the results of the Western Australian Museum/Woodside Energy Ltd. Partnership to explore the marine biodiversity of the Dampier Archipelago, Western Australia 1998-2002. Records of the Western Australian Museum, Supplement 66: 15-17.

Hutchins, J.B., Slack-Smith, S., Berry, P. and Jones, D. (2004). Methodology. In Jones, D.S. (ed.), Report on the results of the Western Australian Museum, Woodside Energy Ltd. Partnership to explore the marine biodiversity of the Dampier Archipelago, Western Australia 1998-2002. Records of the Western Australian Museum, Supplement 66: 3-5.

Jones, D.S. (ed.) (2004 a). Report on the results of the Westem Australian Museum/Woodside Energy Ltd. 
Partnership to explore the marine biodiversity of the Dampier Archipelago, Western Australia 1998-2002. Records of the Western Australian Museum, Supplement 66: vii-xv, 1-401.

Jones, D.S. (2004b). Project objectives. In Jones, D.S. (ed.) Report on the results of the Wostern Australian Muscum/Woodside Energy Ltd. Partnership to explore the marine biodiversity of the Dampier Archipelago, Western Australia 1998-2002. Records of the Westem Australian Museum, Supplement 66: 1 .

Jones, D. and G. Morgan. (2002). A field guide to Crustaceans of Australian waters. Reed: Chatswood, NSW: $224 \mathrm{pP}$

Kamezaki, N., Nomura, K., Hamano, T. and Misaki, H. (1998). Crustacea. Illustrated marine organisms in Okinawa Island, part 8. Southern Press, Okinawa. 232 PP. (in Japanese).

Kato, S. and Okuno, J. (2001). Shrimps and crabs of Hachijo Island. TBS-Britannica Co, Ltd., Tokyo. 157 Pp. (in Japanese).

Kerstitch, A. (1989). Sea of Cortez marine invertebrates. Sea Challengers, Monterey, Califomia. $114 \mathrm{pp}$.

Kim, W. and Abele, L. (1988). The snapping shrimp genus Alpheus from the eastern Pacific (Decapoda: Caridea: Alpheidae). Smithsonian Contributions to Zoology 454: 1-119.

Knowlton, N. and Mills, D. (1992). The systematic importance of colour and colour pattern: evidence for complexes of sibling species of snapping shrimp (Caridea: Alpheidae: Alpheus) from the Caribbean and Pacific coasts of Panama. Proceedings of the San Diego Society of Natural History 18: 1-5.

Kropp, R.K. (1987). Descriptions of some endolithic habitats for snapping shrimp (Alpheidae) in Micronesia. Bulletin of Marine Science 41: 204-213.

McClure, M.R. (2002). Revised nomenclature of Alpheus angulatus McClure, 1995 (Decapoda: Caridea: Alpheidae). Proceedings of the Biological Society of Washington 115: 368-370.
MeClure, M.R. and Wicksten, M.K. (2000), Taxomomic studies of snapping shrimp of the Apheas "Edwardsii" group from the Galapagos Islands (Decapoda: Caridea: Alpheidac). Proceedings of the Biologrical Society of Washington 113:964973.

Minemizu, R. (2000). Marine decapod and stomatopod crustaceans mainly from Japan. Bun-ichi Sogo Shuppan, Tokyo. $344 \mathrm{pp}$. (In Japanese).

Nomura, K. and Asakura, A. (1998). The alpheid shrimps (Decapoda: Alpheidae) collected from Kushimoto, on the Pacific coast of central Japan, and their spatial distributions, zoogeographical affinities, social structures, and life styles. Nankiseibutu: the Nanki Biological Society 40: 25-34 (in Japanese).

Patton, W.K. (1974). Community structure amongst the animals inhabiting the coral Pocillopora damicomis at Heron Island, Australia. Pp. 219-243 In Vernberg, W.B (ed), Symbiosis in the sea. University of South Carolina Press, Columbia, South Carolina.

Slack-Smith, S.M. (2004). Station map and list for the dredging expedition (DA2). In Jones, D.S. (ed), Report on the results of the Western Australian Museum/ Woodside Energy Itd. Partnership to explore the marine biodiversity of the Dampier Archipelago, Western Australia 1998-2002. Records of the Westem Australian Museum, Supplement 66: 19-26.

Wicksten, M.K. (1983). A monograph on the shallow water caridean shrimps of the Gulf of California, Mexico. Unversity of Southern California: Allan Hancock Monographs in Marine Biology 13: 1-59.

Williams, S.T., Knowlton, N., Weigt, L.A. and Jara, J.A.. (2001). Evidence for the three major clades within the snapping shrimp genus Alpheus inferred from nuclear and mitochondrial sequence data. Molecular Phylogenetics and Evolution 20: 375-389. 